\title{
Distribution and controls of petroliferous plays in subtle traps within a Paleogene lacustrine sequence stratigraphic framework, Dongying Depression, Bohai Bay Basin, Eastern China
}

\author{
Ji-Chang Zhu ${ }^{1,2} \cdot$ Cai-Neng Zou ${ }^{3} \cdot$ You-Liang Feng ${ }^{2,3} \cdot$ Shu Jiang ${ }^{4} \cdot$ Wei-An Wu $^{3} \cdot$ Ri-xiang Zhu $^{1,2} \cdot$ Miao Yuan $^{3}$
}

Received: 24 September 2017 / Published online: 29 November 2019

(c) The Author(s) 2019

\begin{abstract}
The characteristics of petroliferous plays in subtle traps within a sequence stratigraphic framework in the Dongying Depression are investigated in this study. Sand bodies within lowstand systems tracts (LSTs) of sequences, comprising incisedchannel fills, sublacustrine fans, deltas in LSTs, controlled by syndepositional normal faults, and sand bodies within transgressive systems tracts (TSTs) to early highstand systems tracts (HSTs), consisting of beach bars, and turbidites, controlled by the prodelta slope, paleorelief, and syndepositional normal faults, are good subtle reservoirs. Mudstones and shale of deep lake subfacies in TSTs to early HSTs of sequences are source and cap rocks. Abnormal overpressure is the dominant dynamic factor for hydrocarbon migration from source rock to the subtle traps. Normal faults, sand bodies, and unconformities function as conduit systems. Sand bodies distributed in the abnormal overpressure source rocks within LSTs to early HSTs are petroliferous plays in lithologic traps. The petroliferous plays in stratigraphic traps are controlled by unconformities at margins of the Depression.
\end{abstract}

Keywords Subtle traps $\cdot$ Sand bodies within lowstand systems tract $\cdot$ Syndepositional normal fault $\cdot$ Abnormal overpressure · Dongying Depression

\section{Introduction}

Within the mature basins that have been explored, most of the traditional and easy-to-find hydrocarbon traps have already been located (Halbouty 1969). Subtle traps, such as lithologic, stratigraphic, and structural and lithologic combination traps, which can hardly be found using the seismic data to recognize structural traps, are now the dominant

Edited by Jie Hao and Xiu-Qiu Peng

You-Liang Feng

fyouliang@ petrochina.com.cn

1 State Key Laboratory of Lithospheric Evolution, Institute of Geology and Geophysics, Chinese Academy of Sciences, Beijing 100029, China

2 University of Chinese Academy of Sciences, Beijing 100049, China

3 Research Institute of Petroleum Exploration and Development, PetroChina, Beijing 100083, China

4 Energy and Geoscience Institute (EGI), University of Utah, Salt Lake City, UT 84108, USA targets for hydrocarbon exploration in these mature basins. For example, in the Mid-continent and Rocky Mountain areas, the flanks of anticlines and synclines for combination subtle traps are recommended for hydrocarbon exploration, even though when tested anticlines on the crests proved dry (Levorsen 1969). In the North Sea basin, subtle traps in the Permian Rotliegend controlled by paleotopography have the potential for hydrocarbon exploration (Maynard and Gibson 2001). Stratigraphic traps created by unconformities and preserved on the unconfined slope of the ancestral Mississippi submarine fans in the northeastern Gulf of Mexico have also been found to contain substantial and profitable hydrocarbon reserves (Godo 2006). In offshore South African divergent basins, Cretaceous traps within lowstand systems tracts (LSTs) of sequences have been recommended for hydrocarbon exploration (Brown et al. 1995). In China, the conventional structural traps have already been found, whereas subtle traps are becoming a greater contributor to the new additions to annual petroleum reserves in the Jiyang Subbasin of the Bohai Bay Basin (Pang et al. 2005).

New theories and methods, including paleotectonic and paleogeomorphic reconstructions (Halbouty 1969), sequence 
stratigraphy (Posamentier and Vail 1988; Van Wagoner et al. 1990; Brown et al. 1995), seismic sedimentology (Zeng and Hentz 2004), and analysis of transfer zones in rift basin (Rosendahl 1987; Morley et al. 1990; Fossen et al. 2010; Paul and Mitra 2013), are used to predict subtle traps. Sequence stratigraphy has been applied successfully to non-marine strata for constructing a sequence stratigraphic framework, interpreting sequence architecture, and forecasting reservoirs in subtle traps (Shanley and McCabe 1994; Lin et al. 2001; Martino 2004; Zecchin et al. 2006; Feng et al. 2013; Jiang et al. 2013; Feng et al. 2016). Abnormal overpressure has been studied in petroliferous basins as a dynamic force for hydrocarbon migration and accumulation in subtle and structural traps (Caillet et al. 1997; Lee and Williams 2000; Zhang et al. 2009a; Guo et al. 2010).

Some studies also have attempted to interpret the distribution and controls of subtle reservoirs by using (1) source rocks (Hu 2010; Jiang et al. 2014), (2) sedimentary facies (Zou et al. 2005), (3) the relationship between porosity and fluid potential (Li and Pang 2004), (4) normal faults and microfractures as conduit systems for hydrocarbon reservoirs of conventional and subtle traps (Losh 1998; Losh et al. 1999; Li et al. 2010; Lampe et al. 2012), and (5) faults controlling hydrocarbon migration and accumulation in a continental rift basin $(\mathrm{Mu}$ 2012; Wei and Su 2015). Some progress has been made in understanding the conditions of hydrocarbon migration and accumulation in subtle traps, and the distribution and controls of subtle reservoirs within the sequence stratigraphic framework in continental rift basins, such as Dongying Depression (Li and Pang 2004; Feng et al. 2005; Pang et al. 2005; Guo et al. 2010, 2012, 2014). In order to perfect the distribution and controls of subtle reservoirs within the sequence stratigraphic framework, this study focuses on four aspects:

First, the sequence stratigraphic framework of Paleogene strata was reconstructed based on 2D and 3D seismic profiles, well logs, and drill cores.

Second, sand bodies in lowstand systems tracts, controlled by sys-depositional normal faults, were identified as reservoirs in subtle traps and described within the sequence stratigraphic framework of Paleogene strata.

Third, the authors describe the types and distributions of hydrocarbon reservoirs in subtle traps as well as investigate conditions of hydrocarbon migration and accumulation.

Finally, the authors discussed the factors controlling petroliferous plays of subtle traps in the sequence stratigraphic framework.

\section{Geological setting and stratigraphy}

\subsection{Geological setting}

The Bohai Bay Basin is a large Cenozoic petroliferous continental rift basin in Eastern China (Fig. 1a). The basin is bounded by Taihang Mountains to the west, Yanshan Mountains to the north, Jiaoliao Uplift to the east, and Luxi Uplift to the south (Allen et al. 1997; Feng et al. 2016). During the Cenozoic era, the Bohai Bay Basin underwent Paleogene rifting and Neogene subsiding stages (Allen et al. 1997; Yang et al. 2016), resulting in thick Paleogene, Neogene, and Quaternary lacustrine deposits. The Bohai Bay Basin consists of several subbasins separated by uplifts (Fig. 1a).

The NE-SW trending Dongying Depression is located in the southeastern part of the Jiyang Subba$\sin$. The area of the depression is about $5700 \mathrm{~km}^{2}$. Paleogene synrift strata of the depression rest unconformably on prePaleogene strata. The Paleogene synrift strata are typically 4000-7000 m (Yao et al. 1994; Zong et al. 1999; Feng et al. 2013).

Raised Precambrian basement blocks are bounded by the Chenjiazhuang Rise to its north, the Luxi Uplift and Guangrao Rise to its south, and the Binxian and Qingcheng Rises to its west (Fig. 1b) (Feng et al. 2013; Pang et al. 2015).

NE-trending extensional structures such as normal faults, northern faulted margin, southern hinged margin, deep troughs/sags, intra-depression fault blocks and transfer zones, anticlines genetically associated with normal faults, and negative flower-shaped structures are developed in an intense dextral transtensional stress field (Allen et al. 1997; Ren et al. 2002; Feng et al. 2010, 2013, 2016) during the Paleogene (Fig. 1b, c).

Besides northern faulted margin and southern hinged margin, the depression can be divided into four sags or subdepressions, such as Minfeng, Lijin, Niuzhuang, and Boxing sags, by two negative flower-shaped structures—one striking $\mathrm{N}-\mathrm{E}$ and one E-W-and one NNW-striking Shicun normalfault belt (Fig. 1b, c).

The structure of the Dongying Depression is a complex half-graben defined by a faulted margin in the north, sags, negative flower-shaped structures at the middle, and a hinged margin in the south (Fig. 1c).

Similar to the Bohai Bay rift basin as a whole, the Depression is complicated by episodic rifting events, including block faulting associated with rapid tectonic subsidence and volcanism (Hsiao et al. 2004, Lin et al. 2004). A twostage evolution model is accepted, with Paleogene synrift and differential subsidence, and Neogene post-rift and thermal subsidence. Paleogene synrift strata formed the major hydrocarbon source rocks, reservoir rocks, and cap rocks in 


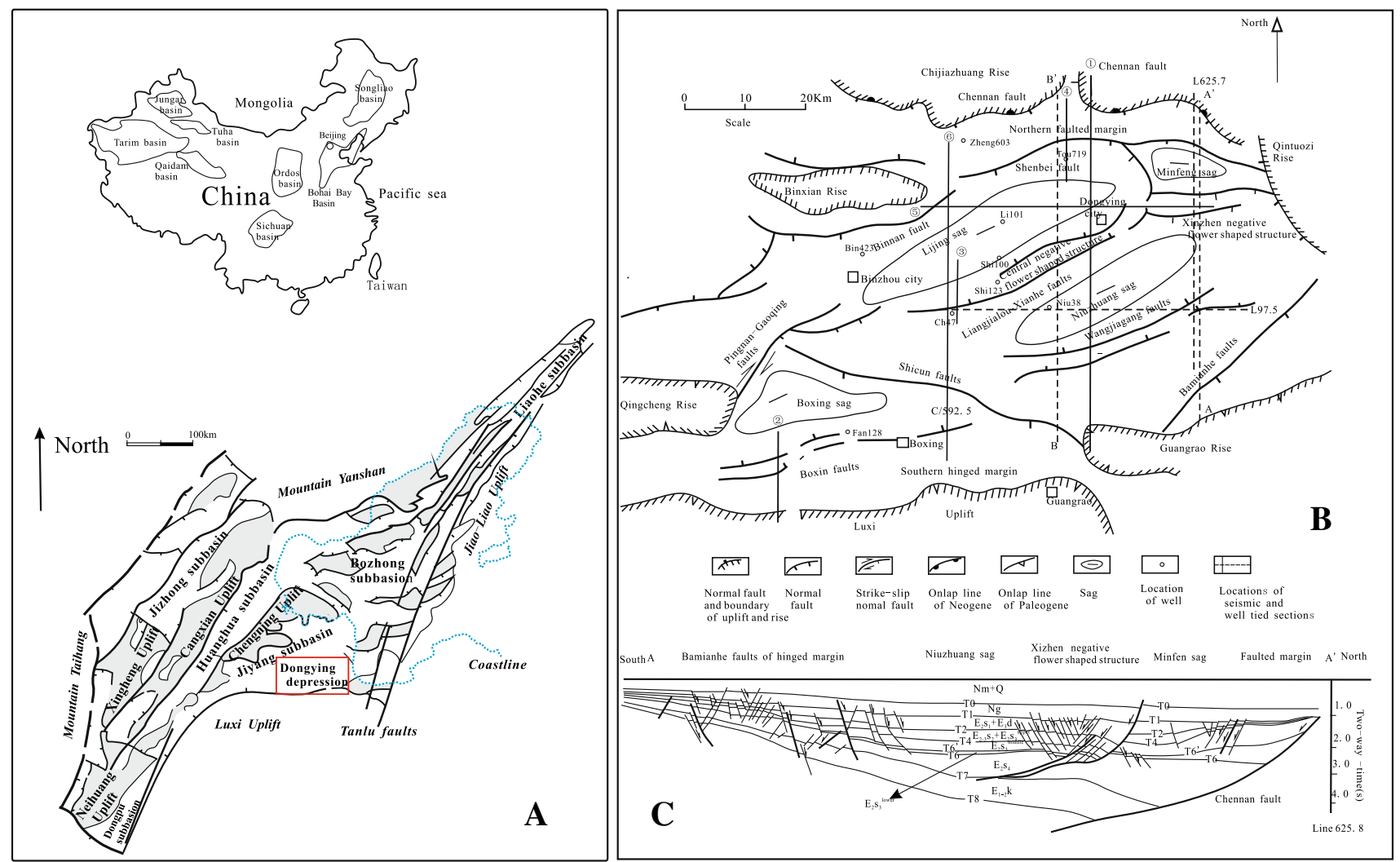

Fig. 1 Tectonic location of Dongying Depression, Bohai Bay Basin, eastern China (a), schematic map of structural units of the Dongying Depression (b), and tectonostratigraphy section (c). The locations of well-tied seismic sections in Fig. 3 a well-tied sequence stratigraphic profile in Fig. 4, well-tied hydrocarbon reservoir sections in Fig. 7 (section (1), 8 (section(2), 9 (section (3), 10 (section (4)), and well-tied EFP profile in Fig. 13 (section (5), 14 (section (6), location of hydrocarbon reservoirs forming pattern of subtle reservoirs (AA') in Fig. 17 are indicated in the map (b). Some important wells are also shown in the map (b) (modified from Feng et al. 2013)

the depression (Fig. 2) (Allen et al. 1997; Wan 2004; Feng et al. 2013).

The Paleogene synrifting stage consists of four rifting episodes (Fig. 2): (1) early-initial rifting beginning in the Paleocene and ending in the Early Eocene (65-50.4 Ma); (2) late-initial rifting in the Middle Eocene (50.4-42.5 Ma); (3) rift climax in the Late Eocene (42.5-38 Ma); and (4) weakened rifting in the Oligocene (38-24.6 Ma) (Feng et al. 2013; Yin et al. 2018).

The Dongying Depression is a typical Paleogene rift basin (Allen et al. 1997; Zong et al. 1999; Wan 2004). It is one of the most petroliferous depressions in the Bohai Bay Basin. Episodic extensional tectonic events and their associated extensional structures and depositional fills have resulted in multiple source rocks ( $\mathrm{Li}$ et al. 2003; Han et al. 2018), combinations of reservoirs and cap rocks, and hydrocarbon reservoirs in structural and subtle traps (Li and Pang 2004). High density of exploration wells has provided a good chance to study the distribution and controls of the hydrocarbon reservoirs in subtle traps and to examine the conditions of hydrocarbon migration and accumulation in subtle traps in rift basins within the sequence stratigraphic framework.

\subsection{Stratigraphy}

The Paleogene strata in the Dongying Depression consist of the Kongdian Formation (E1-2 k) overlain by the Shahejie Formation (E2 s), which is itself overlain by the Dongying Formation (E3d) (Fig. 2).

The lowest part of the second member of the E1-2 k comprises conglomerate, sandstone, and coarse sandstone interbedded with purple to red mudstones. The depositional environments of the interval are interpreted as alluvial fan and braided river ( $\mathrm{Li}$ et al. 1992). The uppermost or youngest part of the second member of the E1-2 k is composed of alternating layers of gray mudstone, oil shale, and medium- to fine-grained sandstones (Fig. 2). The sedimentary environments of the interval are interpreted as deep lake, fluvial delta. The first member of the E1-2 $\mathrm{k}$ comprises alternating layers of red sandstone and gray mudstone; the sedimentary environment of the interval is interpreted as shallow lake (Li et al. 1992; Wang et al. 2016). 


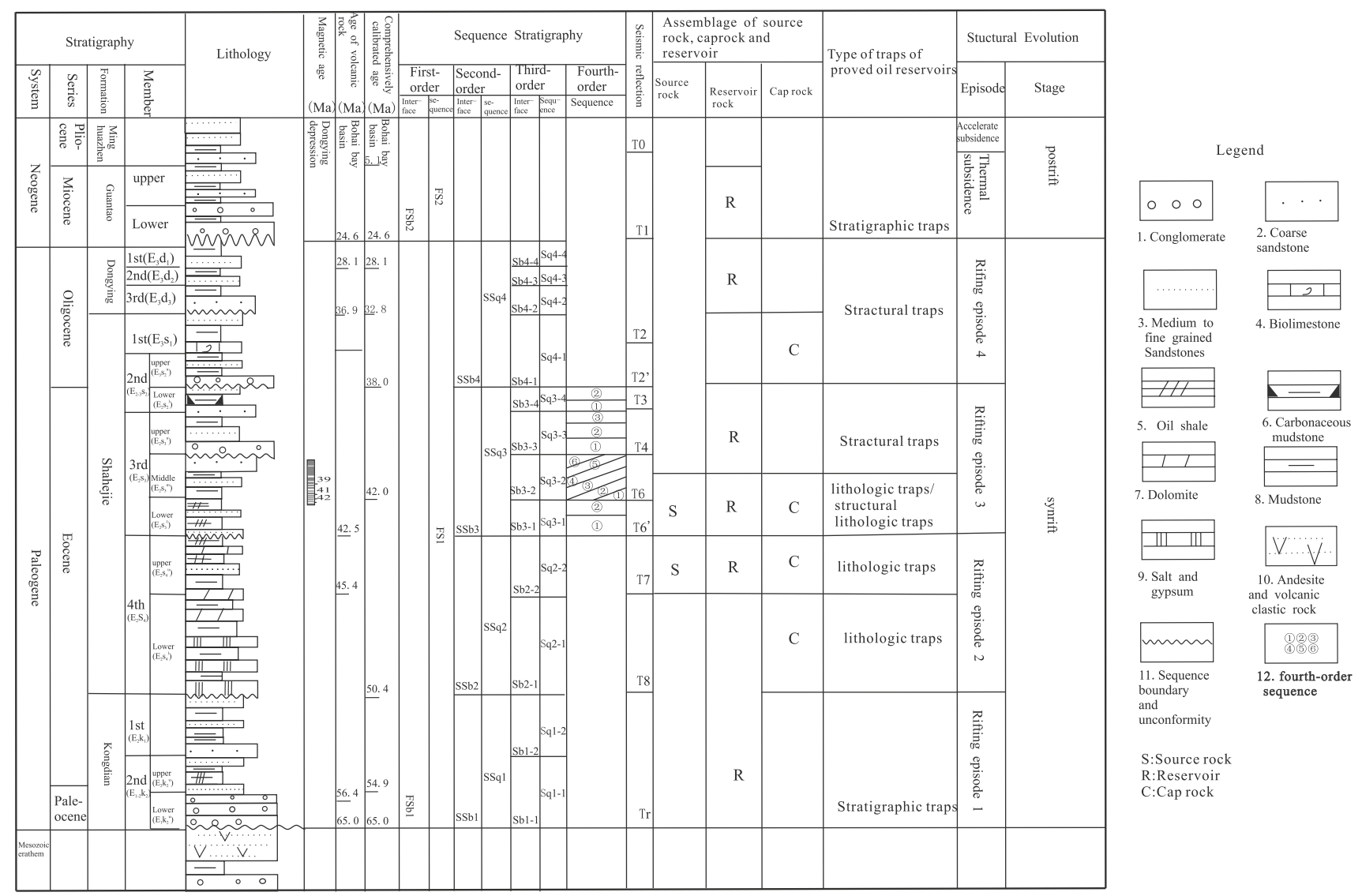

Fig. 2 General sequence stratigraphic charts, and the factors for hydrocarbon accumulation of Paleogene strata in the Dongying Depression (modified from Feng 1999; Feng et al. 2013). The classification of different order sequence stratigraphy is based on the changes in lake level, episodic tectonic activities, assemblage biozones, climate, and detailed work of this paper. The ages of sequence boundaries are determined from micropaleotologic data, e.g., ostracoda and palynologic data, paleomagnetic dating, and volcanic rock dating (Chen and Peng 1985; Li et al. 1992; Yao et al. 1994; Feng 1994). The S is source rock; R is reservoir; C is caprock. FS: first-order sequence; SSq: second-order sequence; Sq: third-order sequence. Sq3-1 means first third-order sequence within second-order sequence 3 (modified from Feng et al. 2013)

The lowest part of the fourth member of Shahejie Formation (E2s4) consists of alternating layers of red sandstone and mudstone interbedded with saline deposits. The sedimentary environment is interpreted as a salt lake (Wang 1992). The top strata of E2s4 are composed of gray mudstone, oil shale intercalated with sandstone, and thin layers of limestone. The sedimentary environment is interpreted as a shallow lake (Song et al. 2012; Lu et al. 2017).

The third member of the Shahejie Formation (E2s3) is Upper Eocene. The lowest strata of the third member (E2s3) comprise gray to dark mudstones and oil shale. The middle and upper parts of the E2s3 are composed of fine sandstone interbedded with gray mudstone, and coarse sandstone and sandy gravels intercalated with green mudstone. The sedimentary environments of E2s3 are interpreted as a deep lake, prodelta, and delta front (Feng et al. 1991, 2013; Feng 1999).

The lowest strata of the second member of the Shahejie Formation (E2-3s2) consist of conglomerate and sandy conglomerate as well as sandstone interbedded with purple to red mudstones. The sedimentary environments of the interval are interpreted as a meandering river and delta plain (Wang 1992; Feng et al. 2013). The top strata of E2-3s2 are composed of conglomerates and coarse sandstones interbedded with red mudstone. The sedimentary environment is interpreted as a braided river (Feng et al. 2013; Wang et al. 2019) (Fig. 2).

The lowest part of the first member of the Shahejie Formation (E3s1) is composed of sandstones interbedded with green and gray mudstones. The middle part of E3s1 comprises gray mudstone and shale interbedded with thin limestone layers. The uppermost part of E3S1 is composed of sandstone interbedded with gray mudstone. The depositional environment of E3S1 is interpreted as a shallow lake (Zhang et al. 2014; Wang 1992; Yan et al. 2019).

The Dongying Formation (E3d) consists of coarse sandstone, medium to fine sandstones interbedded with gray 
mudstone, and gray to greenish mudstone and red mudstone (Fig. 2). The sedimentary environment of the Formation is interpreted as a meandering river (Wang 1992).

\section{Datasets and methods}

This study was based primarily on petroleum geological data from 400 exploration boreholes and regional 3D seismic data covering approximately $5600 \mathrm{~km}^{2}$ in the Dongying Depression (Figs. 1 and 2). The seismic data were extracted from a series of surveys acquired during 1997-2010 and were reprocessed and assembled into a single dataset for this study. Data with a vertical resolution of $15-25 \mathrm{~m}$ in Paleogene strata (derived from a $35-40 \mathrm{~Hz}$ dominant-frequency seismic dataset with a $3600 \mathrm{~m} / \mathrm{s}$ average velocity) are sufficient for the reconstruction of a stratigraphic sequence framework within the region of seismic coverage. Exploration borehole data, including log curves, cores, drill stem test (DST), organic geochemistry data, and results of oil well tests, were also used for this research. The research method of this paper has been described as follows:

1. Interpretation of spontaneous potential curves and seismic profiles was used to identify sequences and systems tracts.

2. The sonic logging data, DST, and results of oil well tests were used to predict abnormal overpressure in strata.

3. Well $\operatorname{logs}$ and 3D seismic data were also used to interpret sand bodies as reservoirs of subtle traps on the basis of the shapes of the spontaneous potential (SP) curves within sequences.

4. Source rocks were evaluated and correlated with oil using organic geochemistry data.

\section{Stratigraphic sequence}

\subsection{Sequence stratigraphy boundaries and hierarchy}

The three orders of unconformities are identified in the Paleogene synrift strata in the Dongying Depression and represent three levels of sequence boundaries: (1) Firstorder unconformities are angular unconformities at the top $(24.6 \mathrm{Ma})$ and bottom $(65.0 \mathrm{Ma})$ of the synrift strata, and the time duration of the two unconformities is $40.4 \mathrm{Ma}$, such as angular unconformities FSb1/Tr (Fig. 3a; Feng et al. 2013) and FSb2/T1 (Fig. 3a); (2) second-order angular unconformities occur between two rifting episodes, and the time duration of the two second-order unconformities is about 4.5-10.0 Ma, such as T8/SSb2, T6/SSb3/Sb3-1, and T2'/SSb4/Sb4-1 (Figs. 2 and 3a, b); (3) third-order unconformities are localized and laterally change to their correlative conformities (Embry 1995, 2002), and the time duration of the two third-order unconformities is about 1.0-2.0 Ma. These unconformities or sequence boundaries can be identified on seismic profiles, logging curves, and drill cores (Feng et al. 2013).

Third-order sequence boundaries appear on the seismic reflection profile as a truncation below the boundary, and onlap above it. Down-dip toward the center of the depression, such boundaries become correlative conformities (Fig. 3a, b; Sb3-1-Sb3-4) (Feng et al. 2013).

In well-tied profiles such as those in Fig. 4, a third-order sequence boundary indicates a scoured base at the bottom of a fining-upward succession from conglomerate at the base to sandstones and mudstones at the top, the fining-upward succession only existed in lowstand systems tracts (LSTs), and the SP curve for such LSTs is bell-shaped. Examples include the base of sublacustrine fans or braided channels (Fig. 4) (Feng et al. 2013). The third-order sequence boundary is also the boundary between the fluvial and deltaic front deposits in lacustrine basins, or subaerial exposure surfaces (Fig. 4) (Feng et al. 2013). Finger-shaped SP curves indicate fluvial deposits; serrated-funnel shapes indicate a delta front deposit within the deltaic succession.

\subsection{Sequence hierarchy}

The stratigraphic architecture of a succession accumulated in a rifted lacustrine basin is different from that in a postrift lacustrine succession (Hubbard 1988; Williams 1993; Carroll and Bohacs 1999; Feng et al. 2000, 2010, 2016). Hubbard (1988) and Williams (1993) classified synrift and post-rift strata as two kinds of first-order sequences through their studies of rifted basins on continental margins.

The synrift (Paleogene) succession in Dongying Depression could be accordingly classified as a first-order sequences 1 (FS1,) confined by first-order unconformities.

FS1 was subdivided into four second-order sequences (SSq) 1 to 4 from bottom to top (SSq1 to SSq4) recognized by second-order unconformities.

SSq1 corresponds to rifting Episode 1 and roughly consists of the Kongdian Formation (E1-2 k), and two third-order sequences (Sqs) are identified in SSq1 based on their characteristic third-order unconformities and correlative conformities (Van Wagoner et al. 1990). SSq2 corresponds to Episode 2 and roughly consists of the fourth member of the Shahejie Formation (E2s4), and two Sqs are recognized in SSq2. SSq3 corresponds to Episode 3 and roughly consists of the third member (E2s3) and the lower part of the second member of 


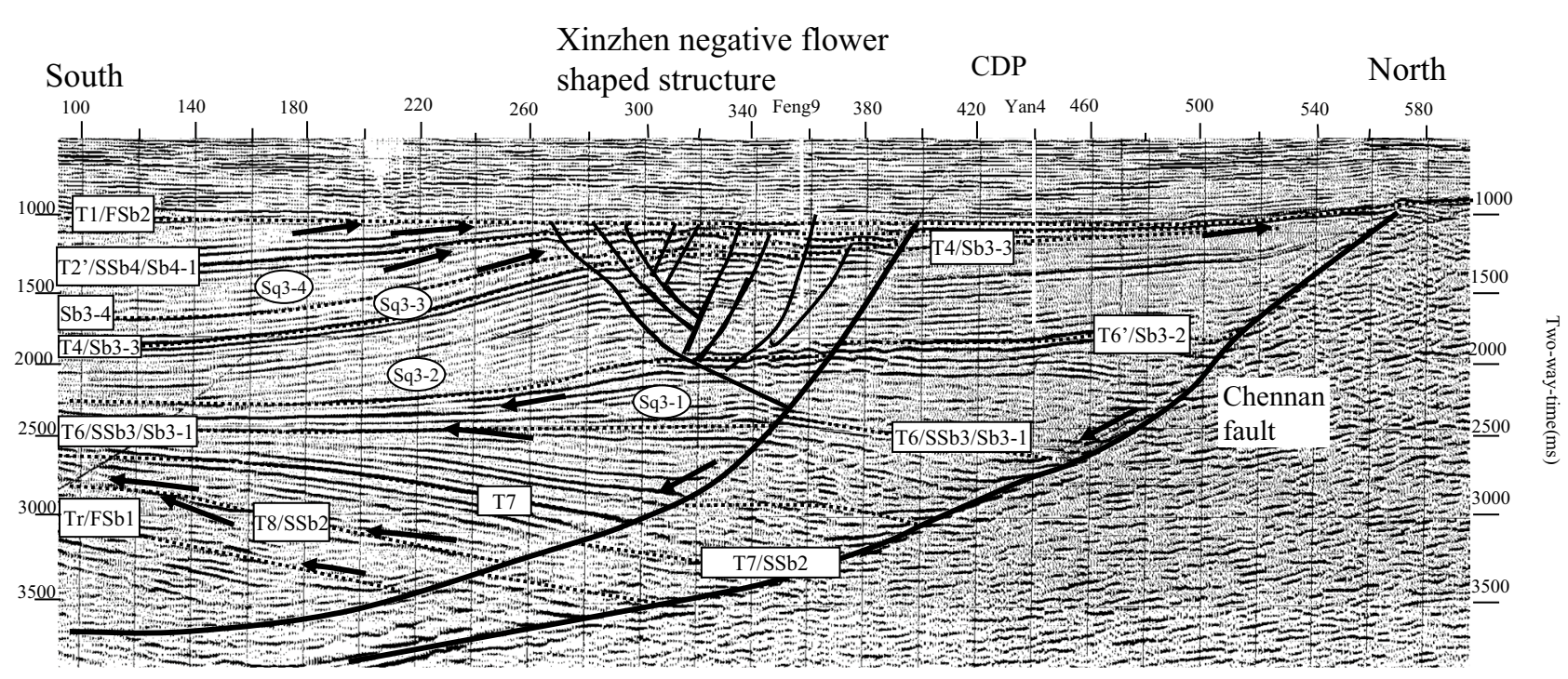

A North to south well-tied seismic section on line 625.7

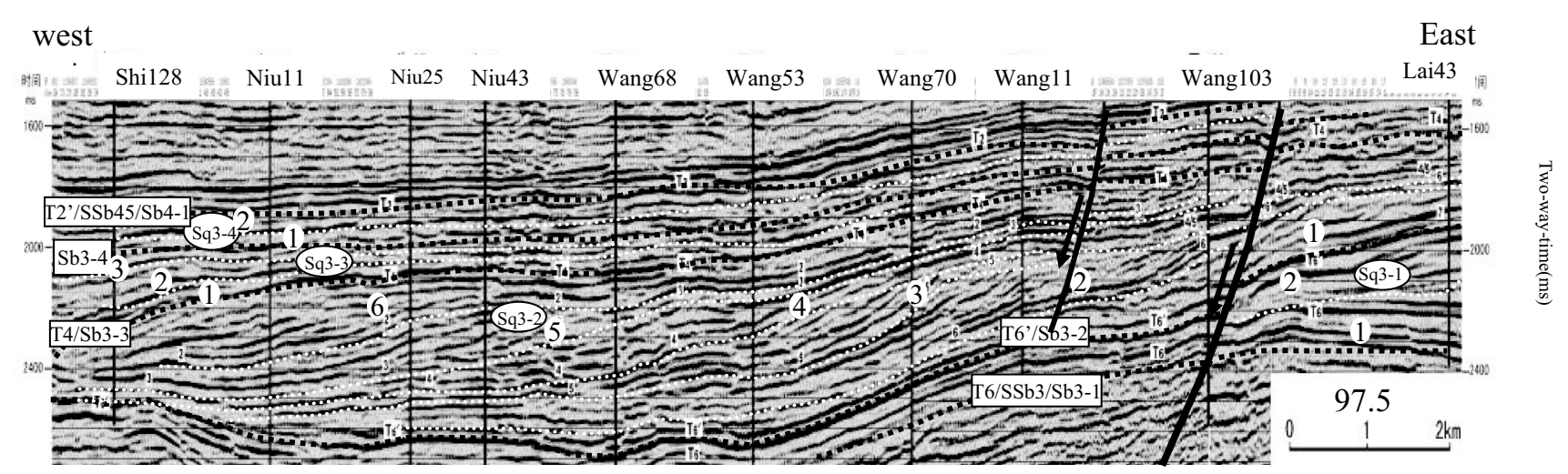

B East to west well-tied seismic section on line 97.5

Fig. 3 Well-tied seismic sections of interpreted structures and sequence stratigraphic framework: a north to south well-tied seismic section on line 625.7 (the location is shown in Fig. 1b); b east to west well-tied seismic section on line 97.5 (the location is shown in Fig. 1b); two-way time is used to indicate buried depth of interfaces of strata. Sq3-1 to Sq3-4 stand for four third-order sequences from bottom to top. The numbers (1) to $(5)$ stand for fourth-order sequences on the seismic profile. $\mathrm{T}$ and $\mathrm{Sb} / \mathrm{SSb} / \mathrm{FSb}$ stand for seismic reflection horizon and sequence boundaries, respectively (Feng et al. 2013)

the Shahejie Formation (E2s2 ${ }^{1}$ ), and four Sqs are identified in $\mathrm{SSq} 3$. SSq4 corresponds to rifting Episode 4 and roughly comprises the upper part of the second member of the Shahejie Formation (E3s2 ${ }^{\mathrm{u}}$ ) to the Dongying Formation (E3d), and four Sqs are recognized in SSq4 (Feng et al. 2013).

Based on the presence of initial (Ifs) and maximum flooding surfaces (Mfs) within third-order sequences as well as stratal terminations and stacking patterns, a series of systems tracts (i.e., lowstand systems tracts (LSTs), transgressive systems tracts, (TSTs), and highstand systems tracts (HSTs)) can be distinguished (Fig. 4).

\section{Reservoirs for subtle traps and their controls}

Based on the seismic data, well logs and cores, and published results (Feng et al. 2013, 2016), the authors identified the sand bodies which are reservoirs for the subtle traps within the sequence stratigraphic framework of the Paleogene strata (Fig. 5; Table 1).

1. Fluvial delta sand bodies with $5 \%-18 \%$ porosity and $1-20 \times 10^{-3} \mu \mathrm{m}^{2}$ permeability within LSTs.

2. Fan-delta sand bodies with $8 \%-15 \%$ porosity and $10-32 \times 10^{-3} \mu \mathrm{m}^{2}$ permeability adjacent to the northern faulted margin (Fig. 4; Feng et al. 2013) within LSTs. 


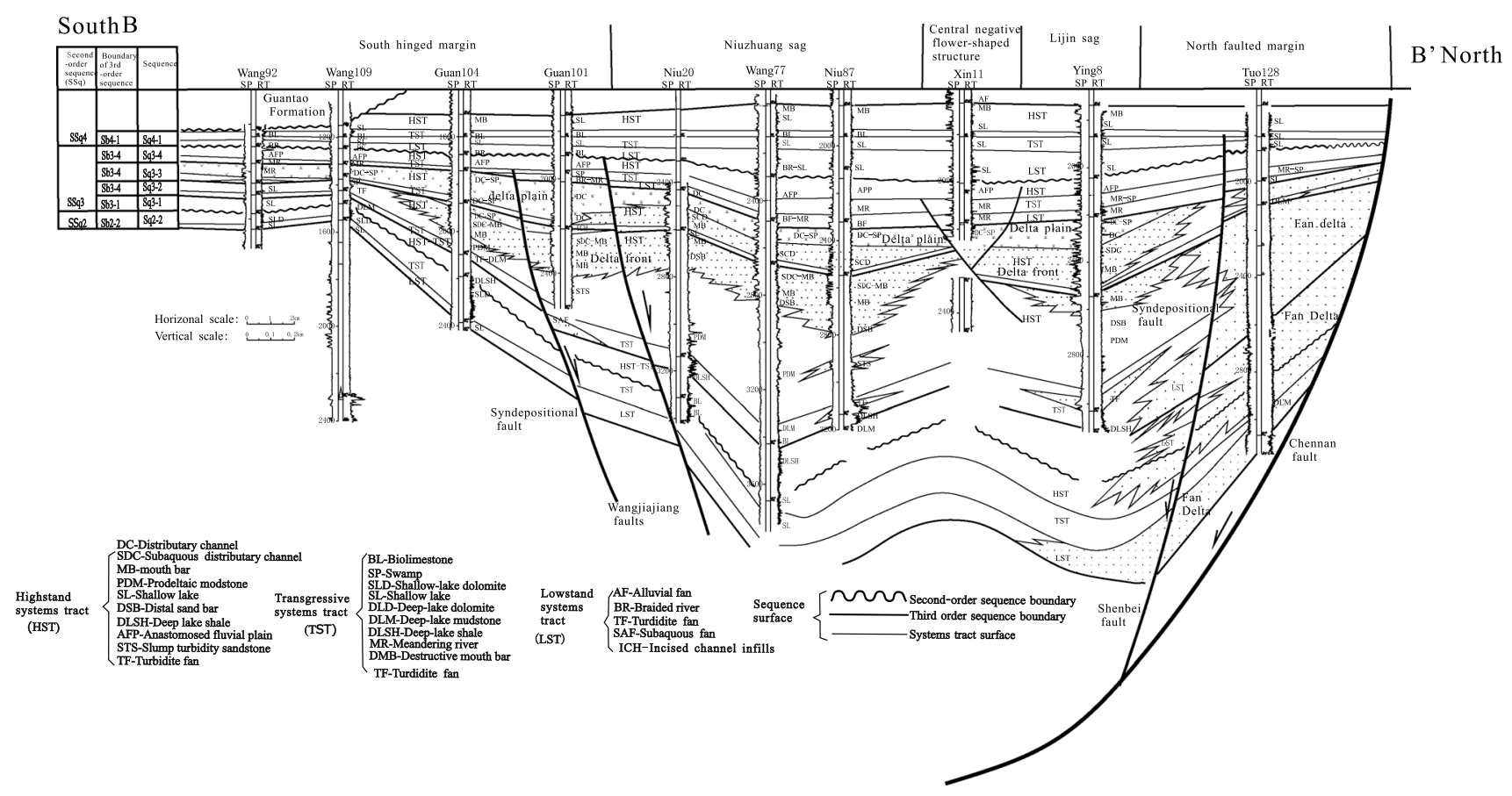

Fig. 4 Well-tied sequences stratigraphic framework from north to south in the Dongying Depression. The location BB' of this cross section is shown in Fig. 1b. The well-tied profile shows the stratigraphic stacking pattern of the third-order sequences in second-order sequence 3 (third member to lower part of second member of Shahejie Formation) at faulted and hinged margins. The curve at the left side of the well is spontaneous potential (SP) log and the curve at the right side of it is the resistivity (RT) log (Feng et al. 2013)

3. Incised-channel fills with $15 \%-20 \%$ porosity and $10-20 \times 10^{-3} \mu \mathrm{m}^{2}$ permeability within LSTs, and sublacustrine fan sand bodies with $15 \%-20 \%$ porosity and $1.4-650 \times 10^{-3} \mu \mathrm{m}^{2}$ permeability at the southern hinged margin in LSTs (Fig. 5; Feng et al. 2013; Table 1).

4. Sand bodies of turbidite fans with $5 \%-13 \%$ porosity and $1.0-10.0 \times 10^{-3} \mu \mathrm{m}^{2}$ permeability within LSTS, TSTs, and early HSTs (Figs. 4 and 5; Feng et al. 2013).

5. Shallow-lake beach bar sand bodies with $6 \%-15 \%$ porosity and $1.0-5 \times 10^{-3} \mu \mathrm{m}^{2}$ permeability along the western and southern ramp slopes of the Depression within TSTs to early HSTs (Fig. 4; Feng et al. 2013).

The distribution of sand bodies in the LSTs of the sequences was controlled by syndepositional faults or syndepositional fault slope-break zones (Feng et al. 2013, 2016). The sand bodies are good reservoirs for subtle traps (Feng et al. 2013). For example, steeply dipping parallel and cross-shaped syndepositional faults were developed mostly at the faulted margins of Sq3-1 and Sq3-2 (Fig. 5; Feng et al. 2013), the sand bodies of fan deltas, turbidite, or sublacustrine fans in LSTs were deposited on the down-dip (lakeward) side of the faults and were found along their length. Only small fluvial deltas in LSTs, controlled by gently dipping parallel syndepositional faults, occurred. In Sq3-3, gently dipping parallel syndepositional faults occurred at the southern hinged margins of the depression, LST sand bodies of turbidite or sublacustrine fans and small deltas, were also deposited on the down-dip (lakeward) side of these faults, and were found along their length too (Fig. 5; Feng et al. 2013). Incised-channel fills within LSTs were deposited on the up-dip (landward) side of the faults.

The sand bodies of beach bars within TSTs and early HSTs were distributed on the ramp or subaqueous high. For example, beach bar sand bodies within TSTs were distributed on the ramp of a hinged margin in Sq2-2 and on the ramp of a faulted margin in Sq3-1, Sq3-2, and Sq3-3. They were controlled by subaqueous highs, such as low buried hills, subaqueous volcanoes, anticlines, and horsts, and were distributed along slopes of subaqueous highs (Song et al. 2012; Feng et al. 2013).

Sand bodies of sublacustrine or turbidite fans within TSTs and early HSTs, including sandy debrites and turbidites, were developed in deep lake and on prodelta slopes and were controlled by the slopes and normal faults, respectively (Feng et al. 1991; Zou et al. 2012; Liu et al. 2017). 


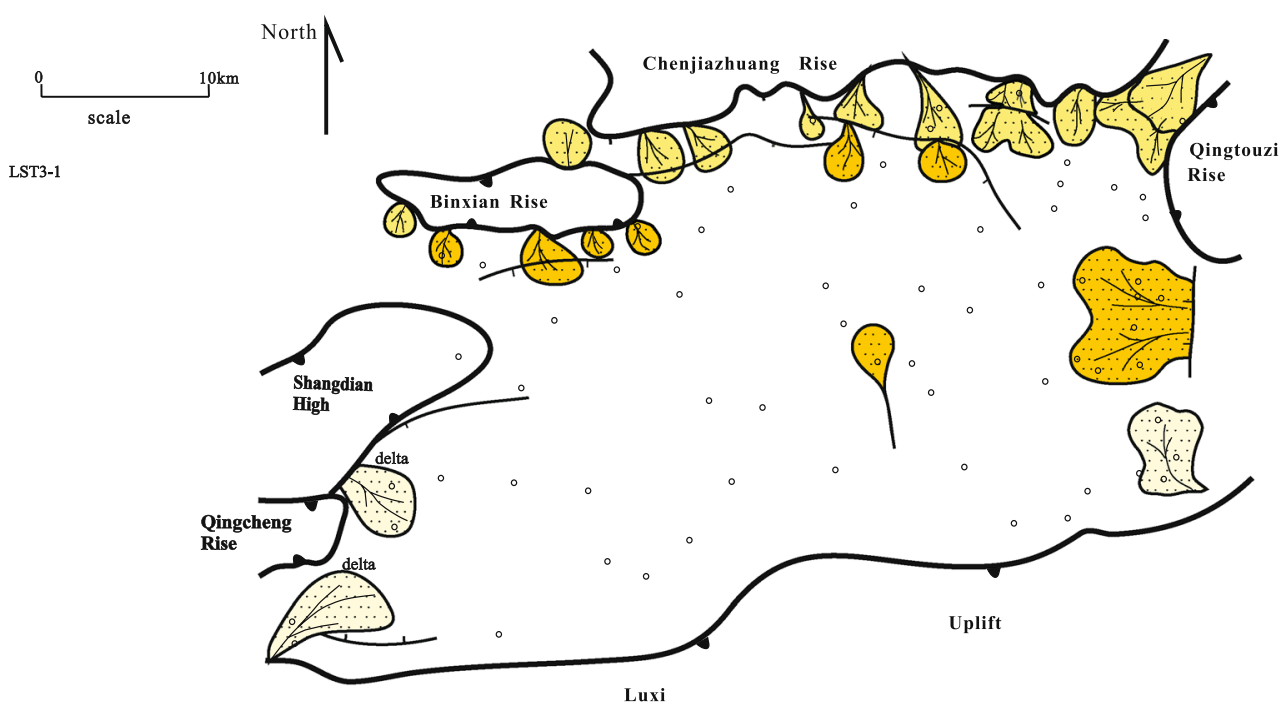

LST3-2

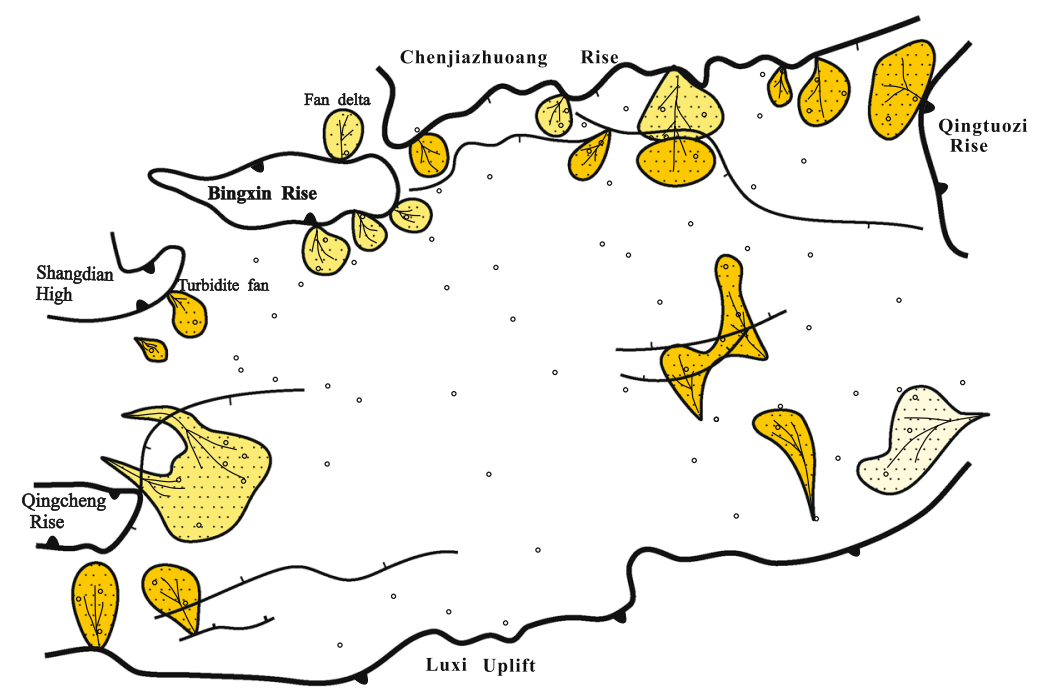

LST3-3

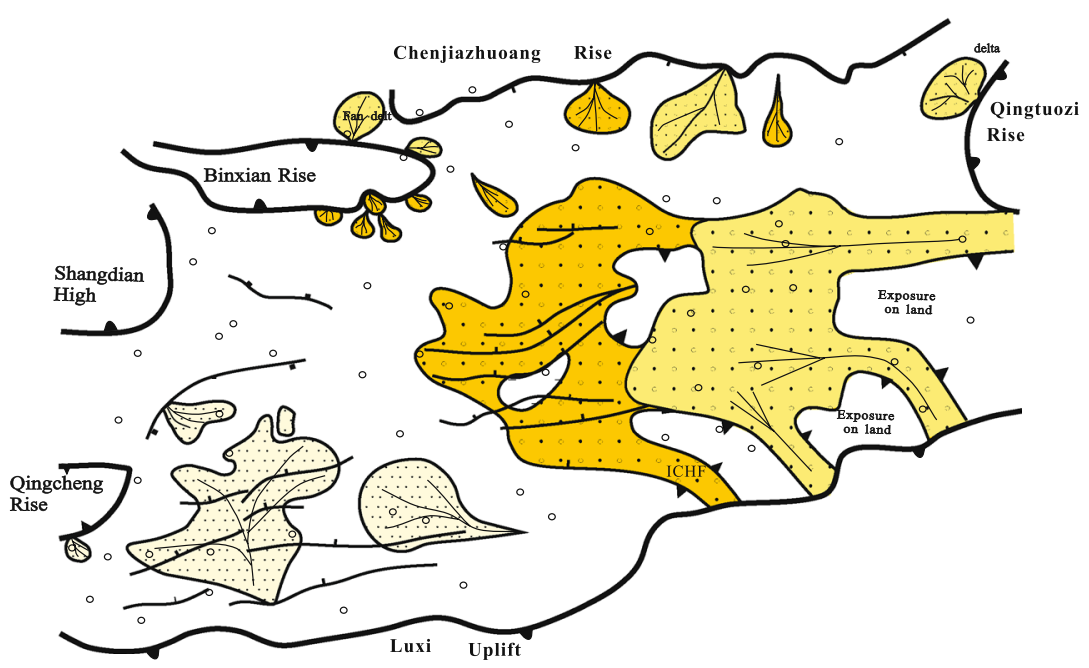

Fig. 5 Distribution maps of sand bodies within LSTs of Sq3-1 to Sq3-3 in Dongying Depression (Feng et al. 2016) 
Table 1 Reservoir physical property of sand bodies in lowstand systems tracts (the reservoir physical property data based on Li and Pang 2004, and Petroleum Geological Institute of Shengli Oil Field Corporation Ltd., Sinopec Corp.)

\begin{tabular}{lccll}
\hline Type of sand body & Porosity $(\%)$ & Permeability $\times 10^{-3} \mu \mathrm{m}^{2}$ & Area/well & Systems tracts \\
\hline Sublacustrine fan & $15-20$ & $1.4-650$ & Lijin sag & LST \\
Incised-channel fill & $15-20$ & $10-20$ & S103 & LST \\
Fan delta & $8.0-15$ & $10-32$ & Well T71 & LST \\
Fluvial delta & $5-18$ & $1-20$ & F104 & LST \\
Turbidite fan & $5-13$ & $1-10$ & L911 & TST \\
Brach bar & $6-15$ & $1-5$ & Linfanjia & TST \\
\hline
\end{tabular}

\section{Types of subtle traps and subtle reservoirs}

The Paleogene subtle traps and subtle reservoirs in the Dongying Depression occurred in two petroleum plays, one in the source rocks of the upper part of $\mathrm{E} 2 \mathrm{~s} 4(\mathrm{Sq} 2-2)$ and E2s3 (including Sq3-1 and Sq3-2, Sq3-3) and the other in E2s2 to E2d, which are far away from source rocks (including Sq3-4 and Sq4-1 to Sq4-4) (Fig. 2) (Li et al. 2003, 2010; Zhang et al. 2009b; Guo et al. 2012; Chen et al. 2016). Subtle traps and subtle reservoirs in the Depression include (1) lithologic traps and lithologic reservoirs; (2) stratigraphic traps and stratigraphic hydrocarbon reservoirs; and (3) structural and lithologic combination traps and their reservoirs (Fig. 6).

\subsection{Lithologic traps and lithologic reservoirs}

The lithologic traps formed by lithologic variation, such as lenticular sand bodies and up-dip sandstone pinch-out, are widespread in the strata from Sq2-2 (the upper part of E2s4) to Sq3-2 (the middle part of E2s3) (Figs. 7 and 8). They were developed in source rocks and in sags. Based on a sedimentary study, they consist of sublacustrine fan or turbidity deposits that developed in LSTs to TSTs of the Sq3-1 (the lower part of E2s3) and Sq3-2 (the middle part of E2s3) source rocks (Feng et al. 2013) and beach bar deposits that developed in Sq2-2 (the upper part of E2s4) (Song et al. 2012).

The lateral extent and quality of the reservoirs vary substantially because of diagenesis and facies variation. The porosity of the lenticular sand bodies of turbidite fans and beach bars was approximately $5 \%-13 \%$ and $6 \%-15 \%$, respectively, with permeability of approximately $1-10 \times 10^{-3} \mu \mathrm{m}^{2}$ and $1-5 \times 10^{-3} \mu \mathrm{m}^{2}$, respectively (Table 1 ). The up-dip sand body pinch-out was developed along flanks of paleostructure highs on the western margin in the Depression, as well as on gentle southern slopes (Figs. 4, 7, and 8). The sand bodies forming up-dip and pinch-out were the dominant sand bodies of the sublacustrine fans and deltaic fronts in LSTs (Figs. 4, 7, and 8 ). The porosity and permeability of the up-dip sand bodies were greater than those of the lenticular sand bodies (Table 1; Li and Pang 2004).

Hydrocarbon reservoirs of lenticular sand bodies of turbidite fans did not have unified oil-water contacts, and each hydrocarbon reservoir had an oil-water contact (Figs. 7 and 8). They were distributed in the Sq3-2 (the middle of E2s3) source rock of Lijin and Niuzhuang sags, for example, in the hydrocarbon reservoir of the lenticular sand body traps of turbidite fan drilled through by the Well Ying 11 in the Lijin sag (Fig. 7). Hydrocarbon reservoirs of up-dip sandstone pinch-out occurred mainly on the southern hinged margin. Oil was found only near the top of the individual up-dip and pinch-out sand body (Figs. 7 and 8).

\subsection{Stratigraphic traps and stratigraphic hydrocarbon reservoirs}

Stratigraphic traps, including stratigraphic unconformity and stratigraphic overlap traps, were formed by stratigraphic truncation below unconformities or sequence boundaries, with an onlap above the unconformities, which were widespread in the Paleogene strata at the southern hinged margin (Figs. 6, 7, and 8). Beach bar and deltaic front sandstones, with good physical properties, constitute reservoirs in stratigraphic traps (Guo et al. 2014). The traps were capped by the unconformities and mudstones near them. In the Depression, the hydrocarbon from Sq2-2, Sq3-1, and Sq3-2 mature source rocks migrated up faults, sand bodies, and unconformities to form stratigraphic hydrocarbon reservoirs including stratigraphic unconformity reservoirs and stratigraphic overlap reservoirs ( $\mathrm{Li}$ et al. 2010). The Jingjia oilfield (Fig. 8) at the southern hinged margin is a typical example. The first-order unconformity between Neogene and Paleogene and the second unconformity between Sq4-1 and Sq3-4 control the distribution of stratigraphic hydrocarbon reservoirs. 


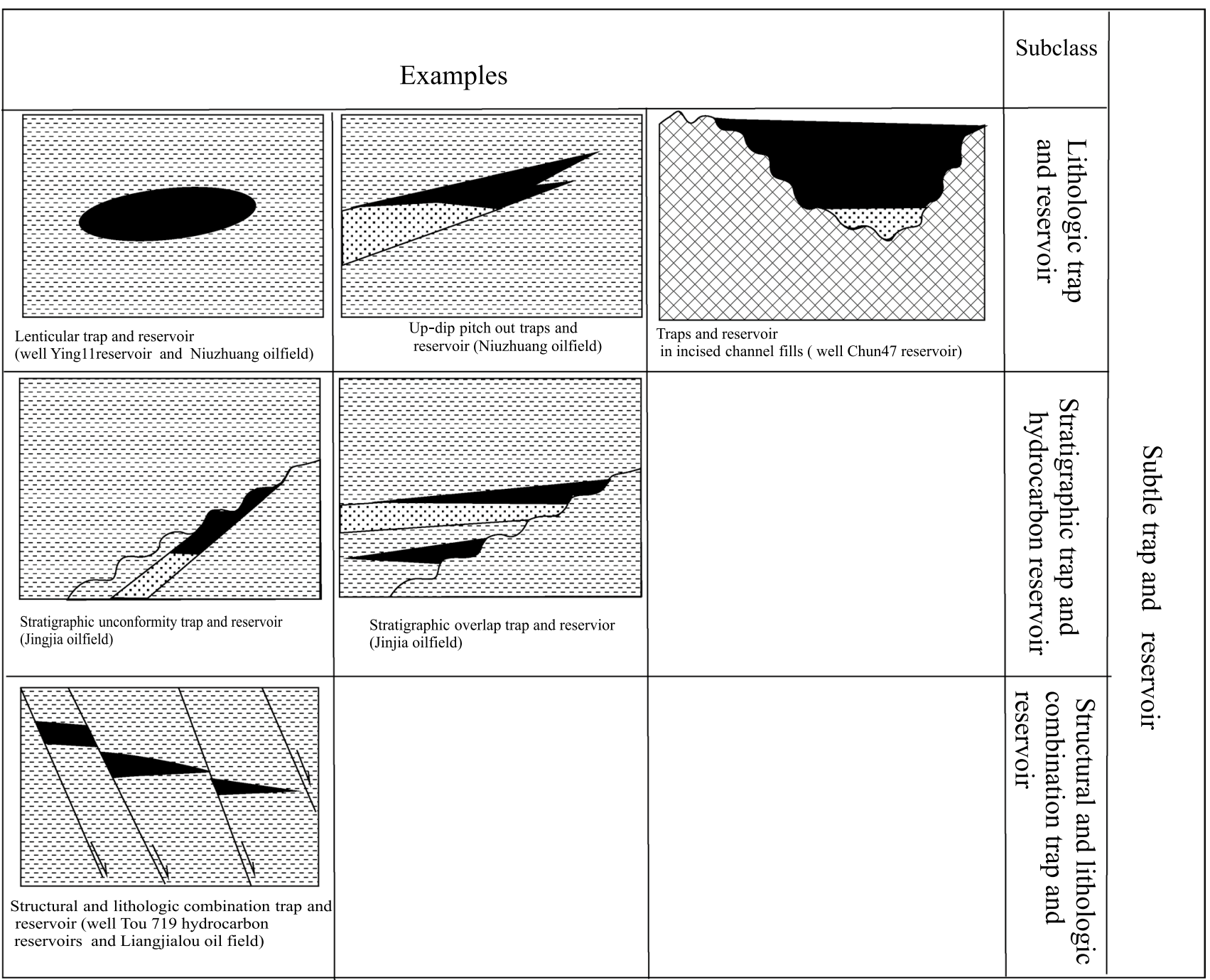

Fig. 6 Classification maps of subtle traps and hydrocarbon reservoirs in Dongying Depression based on explored examples

\subsection{Lithologic and structural combination traps and hydrocarbon reservoirs}

Based on features of hydrocarbon reservoir profiles (Figs. 7, 8,9 , and 10), lithologic and structural combination traps are a kind of the subtle traps in the Depression too (Figs. 6, 7, 9, and 10). According to depositional facies maps (Fig. 5) and logging data, the trap reservoirs were made of sandstones of sublacustrine fans with $15 \%-20 \%$ porosity and $1.4-650 \times 10^{-3} \mu^{2}$ permeability, delta with $5 \%-18 \%$ porosity and $1-20 \times 10^{-3} \mu^{2}$ permeability, and incised-channel fills with $15 \%-20 \%$ porosity and $10-20 \times 10^{-3} \mu \mathrm{m}^{2}$ permeability in LSTs (Fig. 5, Table 1). They are capped by deep lacustrine mudstone and oil shale in TSTs (Figs. 7, 9, and 10). The traps were lateral pinch-out or facies change and were cut up-dip by normal faults (Figs. 7, 9, and 10). They have the potential to form petroleum plays whose proven reserve can exceed 50 million tons (360 million bbl), such as the Liangjialou oilfield (Hao et al. 2005), which is a typical example in subtle reservoirs in a lithologic structural combination trap (Fig. 9). Their reservoirs are sand bodies in LST3-3 within Sq3-3 (Figs. 5 and 9). These sand bodies belong to deposits in incised-channel fills and sublacustrine fans (Figs. 5 and 9; Feng et al. 2013). They were capped by TST3-3 deep lake mudstone and cut up-dip by normal faults (Fig. 9). The geochemical properties of the oils have intermediate values between those observed in extracts from the TST3-1 (the lower part of E2s3) and Sq2-2 (the upper part of E2s4) source rocks (Zhang et al. 2004; Hao et al. 2005; Li et al. 2010). As a consequence, the oils in the subtle traps were most likely derived from mixed Sq3-1 and Sq2-2 source rocks, with a predominant contribution from the Sq2-2 source rocks (Hao et al. 2005; Li et al. 2010). Hydrocarbon may have migrated up faults from Sq2-2 and 


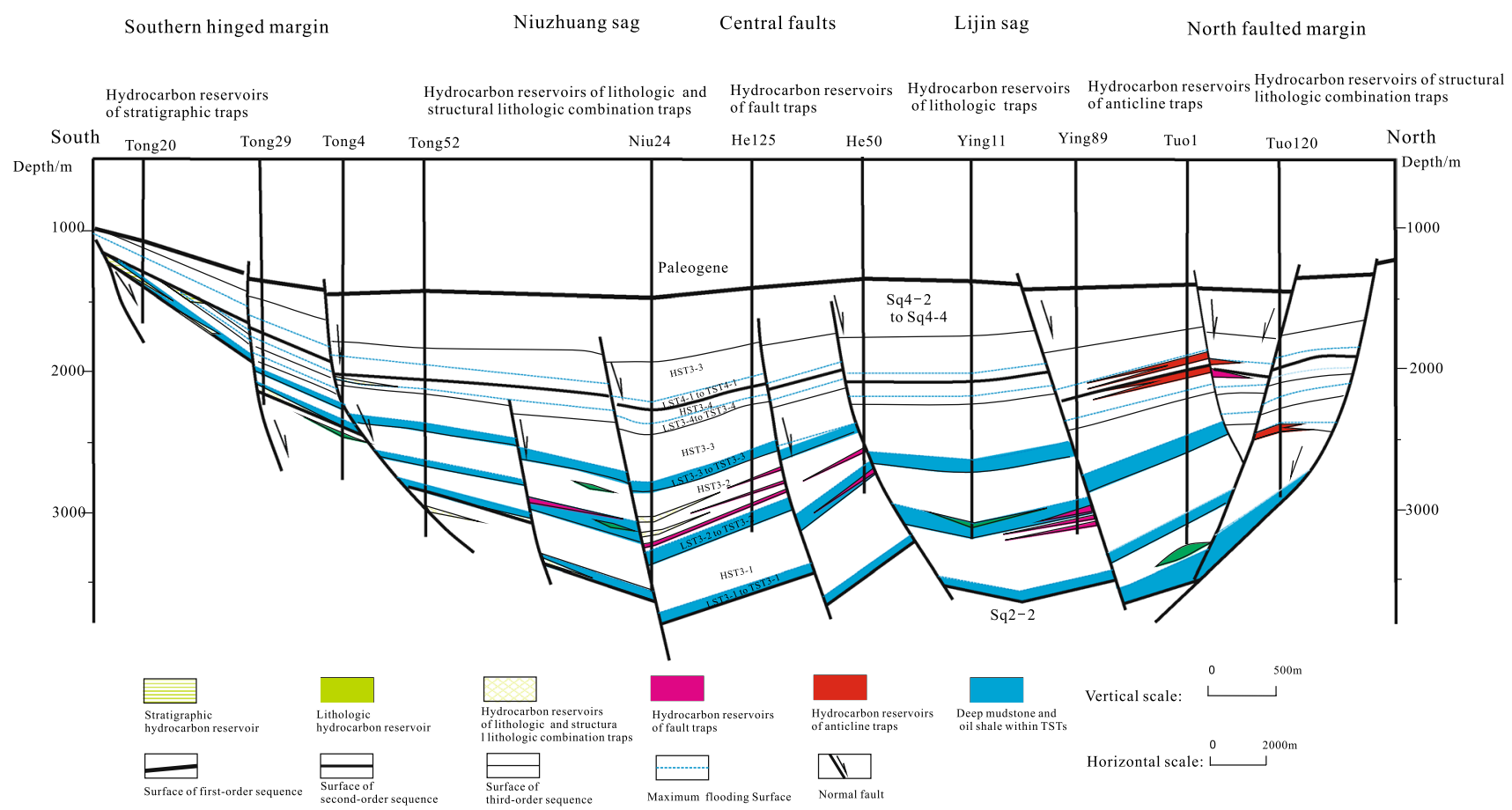

Fig. 7 Well-tied profile of hydrocarbon reservoirs in Dongying Depression from north to south. The location of the profile (1) is indicated in Fig. 1b. Symbols of sequences are shown on the profile same as Fig. 2

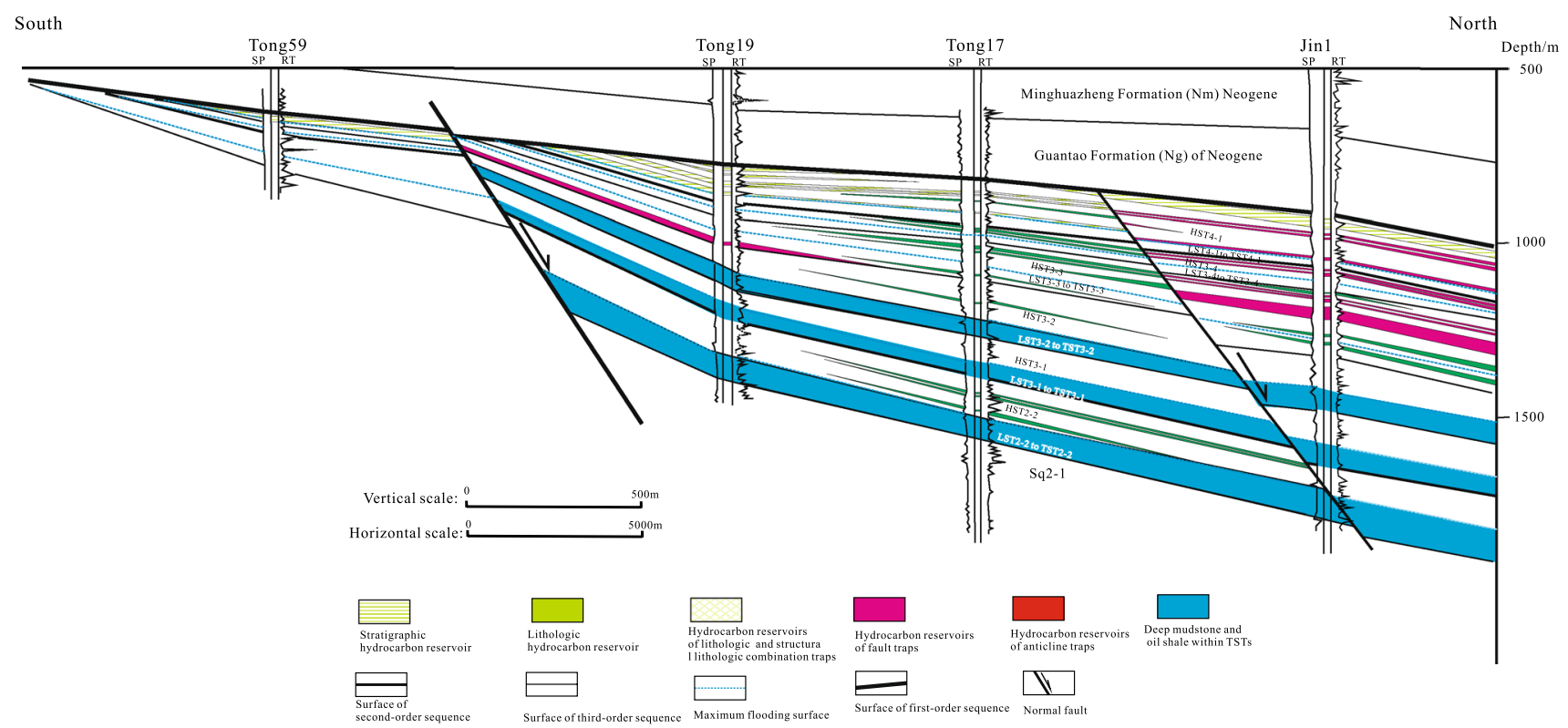

Fig. 8 Well-tied profile of hydrocarbon reservoirs at Jingjia oilfield within the sequence stratigraphic framework from north to south at southern hinged margin. The location of the profile (2) is indicated in Fig. 1b. RT is resistivity curve, SP is spontaneous potential curve. Symbols of sequences are shown on the profile same as Fig. 2

Sq3-1 source rocks to these subtle traps (Fig. 9). Another example is the Tou71 subtle reservoirs at the northern faulted margin (Fig. 10). The reservoirs, ranged from fan deltaic sandstone to conglomerate with $8 \%-15 \%$ porosity and $10-32 \times 10^{-3} \mu^{3}$ permeability in the LST3-2 of Sq3-2, were capped by deep TST2 lake mudstone and were lateral pinch-out or facies change and cut by faults. Hydrocarbon from Sq2-2 and Sq3-1 migrated to the subtle traps up faults. 


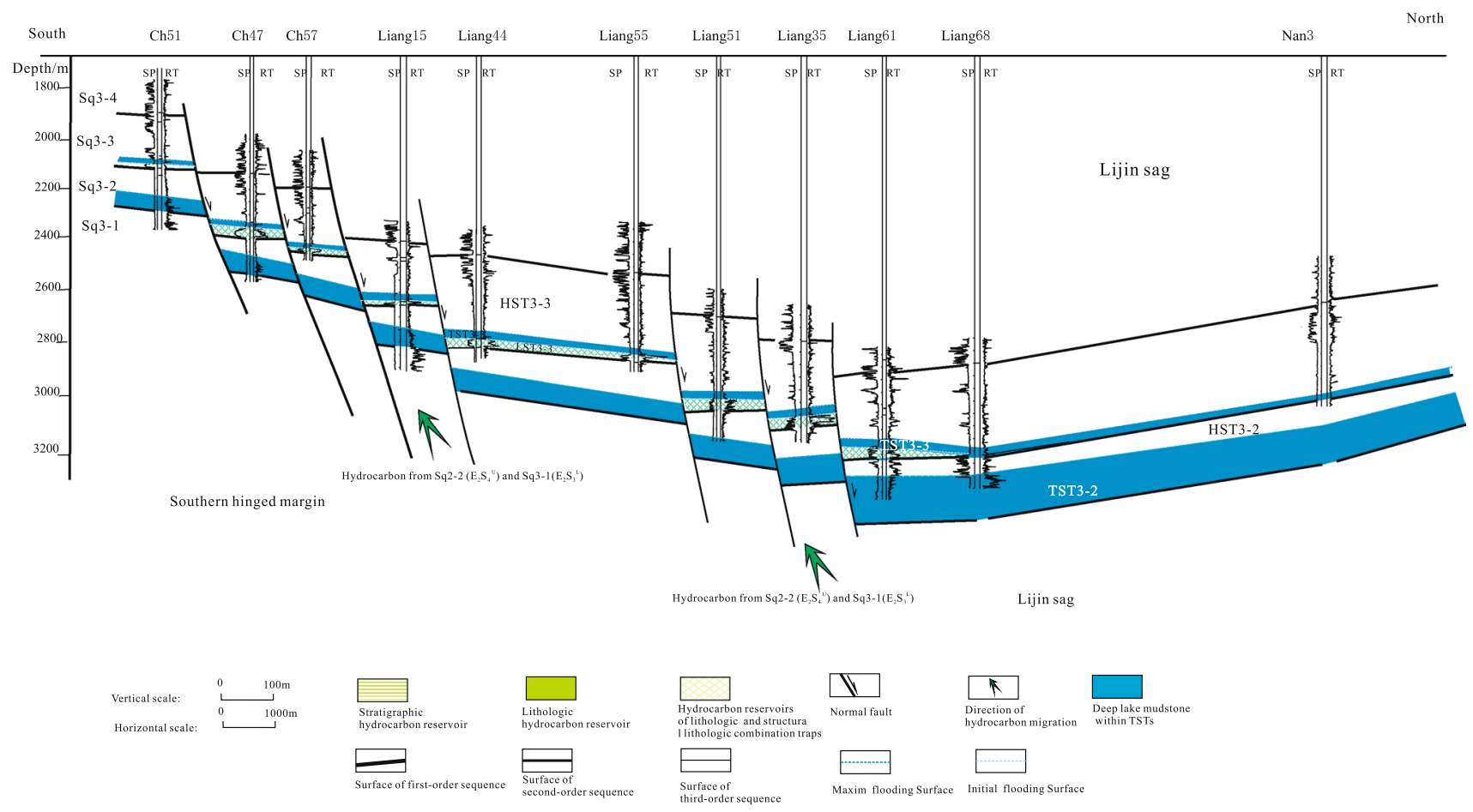

Fig. 9 Well-tied profile of hydrocarbon reservoirs of structural/fault and lithologic combination traps within systems tracts of sequence Sq3-3 from north to south at Liangjialou oilfield. The location of the profile (3) is indicated in Fig. 1b

The source rocks in TST3-2 within Sq3-2, such as shale and mudstone, capped on the traps, could also migrate to the subtle traps directly (Fig. 9).

\section{Distribution features and genesis of abnormal overpressure}

\subsection{Distribution features of abnormal overpressure}

DST data and sonic loggings show that abnormal overpressure develops in Sq3-1 and Sq3-2 strata (Xie 2001; Zhang et al. 2009a, b; Guo et al. 2010; Hao 2013). Abnormal overpressure is a dominant dynamic factor for hydrocarbon accumulation in subtle traps in abnormal overpressure strata (Losh 1998; Losh et al. 1999; Li et al. 2004; Guo et al. 2010, Lampe et al. 2012). To distinguish abnormal overpressure, pressure coefficient (PC) and excess fluid pressure (EFP) are used in this study. The pressure coefficient is a ratio of the actual pore pressure versus the normal hydrostatic pressure at the same depth. The EFP is a value of the actual pore pressure of strata subtracted from the normal hydrostatic pressure. Because of the limited amount of DTS data, sonic logging of 300 boreholes was used to predict the fluid pressure, the fluid pressure coefficient, and the EFP. Using these parameters, the characteristics of the overpressure were studied.

Based on the results of fluid pressure calculated by Feng et al. (2006) using sonic logging of 300 wells, the features of the fluid pressure of wells in the depression can be divided into two types: normal fluid pressure of wells at margins and shallow wells, and abnormal high fluid pressure of deep wells at sags (Fig. 11). Within abnormal overpressure areas, such as Well Li101 in the Lijin sag (Fig. 11), fluid pressure can be divided into further three parts. When the depth of the well is less than $2200 \mathrm{~m}$, the strata fluid pressure is equal to the hydrostatic pressure. When the well depth is between 2200 and $3000 \mathrm{~m}$, the fluid pressure coefficient (PC) of the strata is between 1.0 and 1.2. The depth between $2200 \mathrm{~m}$ and $3000 \mathrm{~m}$ is called the transition zone of fluid pressure. When the well depth exceeds $3000 \mathrm{~m}$, the PC is greater than that of 1.2, and the fluid overpressure occurs (Fig. 12).

The plane view and profile distribution of EFP of mudstone can be drawn using EFP data calculated from sonic logging by Feng et al. (2006) (Figs. 12, 13, and 14). On the EFP map of the bottom of Sq3-2, high EFP (> 16 Mpa) was distributed at Lijin, Boxing, Niuzhuang, and Minfeng sags. The mean value of EFP occurred in the structural belts between sags. At the southern margin, EFP was equal to 0, and fluid pressure was hydrostatic (Fig. 13). On the welltied sections of EFP, the top surface was shallower at the 


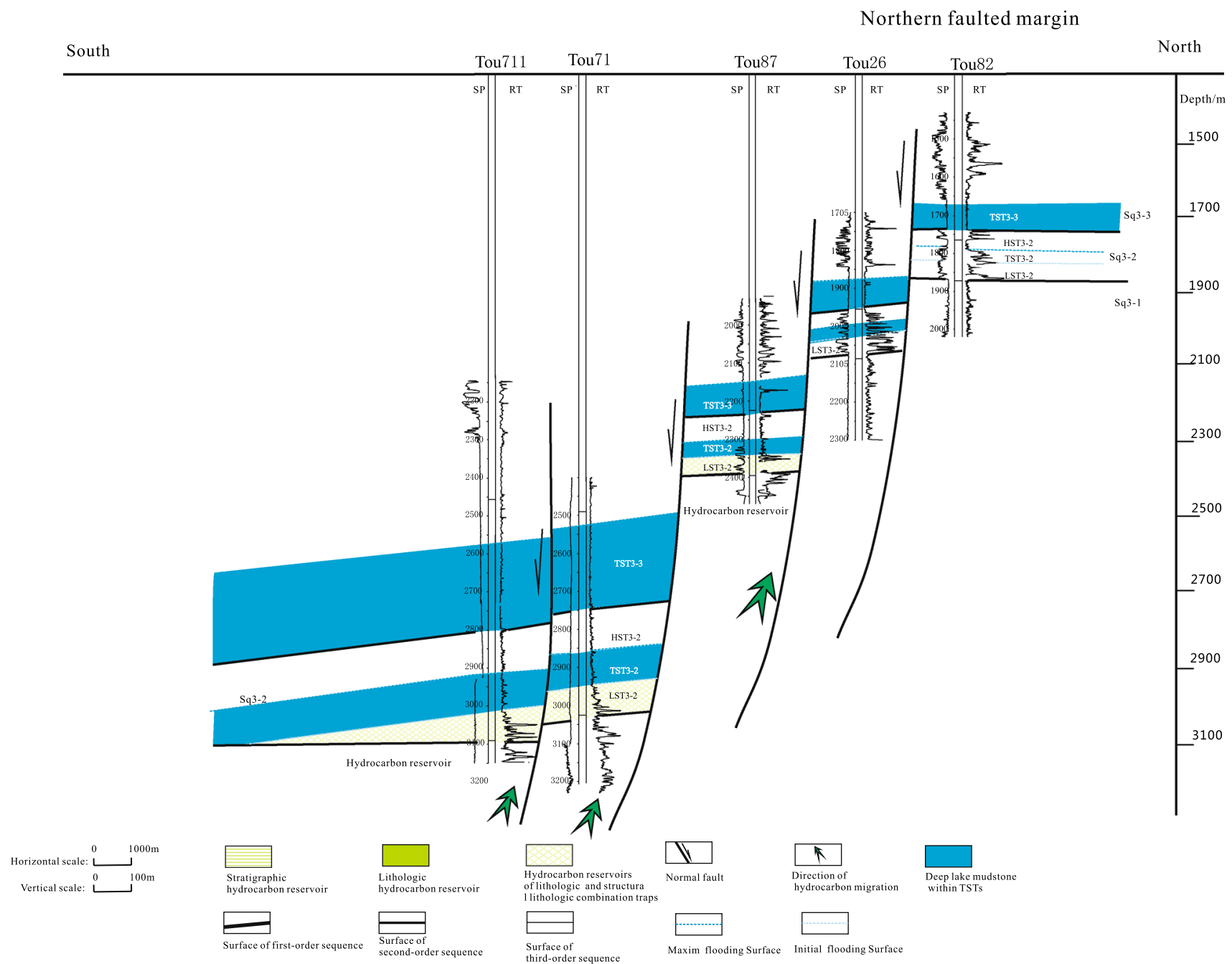

Fig. 10 Well-tied hydrocarbon reservoir profile of Tou71 structural/fault and lithologic combination hydrocarbon reservoirs within systems tracts of sequence Sq3-2 at faulted margin from north to south. The location of the profile (4) is indicated in Fig. 1b

central negative flower shape structural belt, fault belts, and the margins, and deepened at sags, for example, at the Lijin and Minfeng sags. The highest fluid overpressure occurred in strata from Sq2-2 to Sq3-1 and at Sq3-2 (Fig. 12).

\subsection{The genesis and significance of abnormal overpressure}

In general, mechanism for overpressure includes compaction disequilibrium (Rubey and Hubert 1959; Magara 1975; Mara et al. 2009; Ramdhan and Goulty 2011; Lahann 2017), hydrocarbon generation (Bredehoeft et al. 1994; Guo et al. 2010), and fluid release during dehydration reactions (Magara 1975; Hooker et al. 2017). However, clay dehydration cannot generate significant overpressure unless there is a perfect seal (Luo and Vasseur 1992; Osborne and Swarbrick 1997). Therefore, the major mechanisms for overpressure development are compaction disequilibrium and hydrocarbon generation in the Depression.

Some researchers think compaction disequilibrium is the dominant mechanism for overpressure generation in the Dongying Depression (Xie et al. 1998; Xie 2001). The reason is if fluids cannot be expelled sufficiently when a formation is increasing rapidly, the disequilibrium compaction occurs rapidly (Osborne and Swarbrick 1997; Hooker et al. 2017). However, in Dongyin Depression, there are no apparent characteristics of compaction disequilibrium, such as anomalously high porosities or low density in the overpressured mudstones (Guo et al. 2010). Therefore, the overpressure of mudstones was not generated by compaction disequilibrium, for they are under normal compaction. Other data, such as the sedimentary rate of strata and the hydrocarbon potential of source rocks, show that overpressure correlated with hydrocarbon generation other than 
P/Mpa (Pressure)

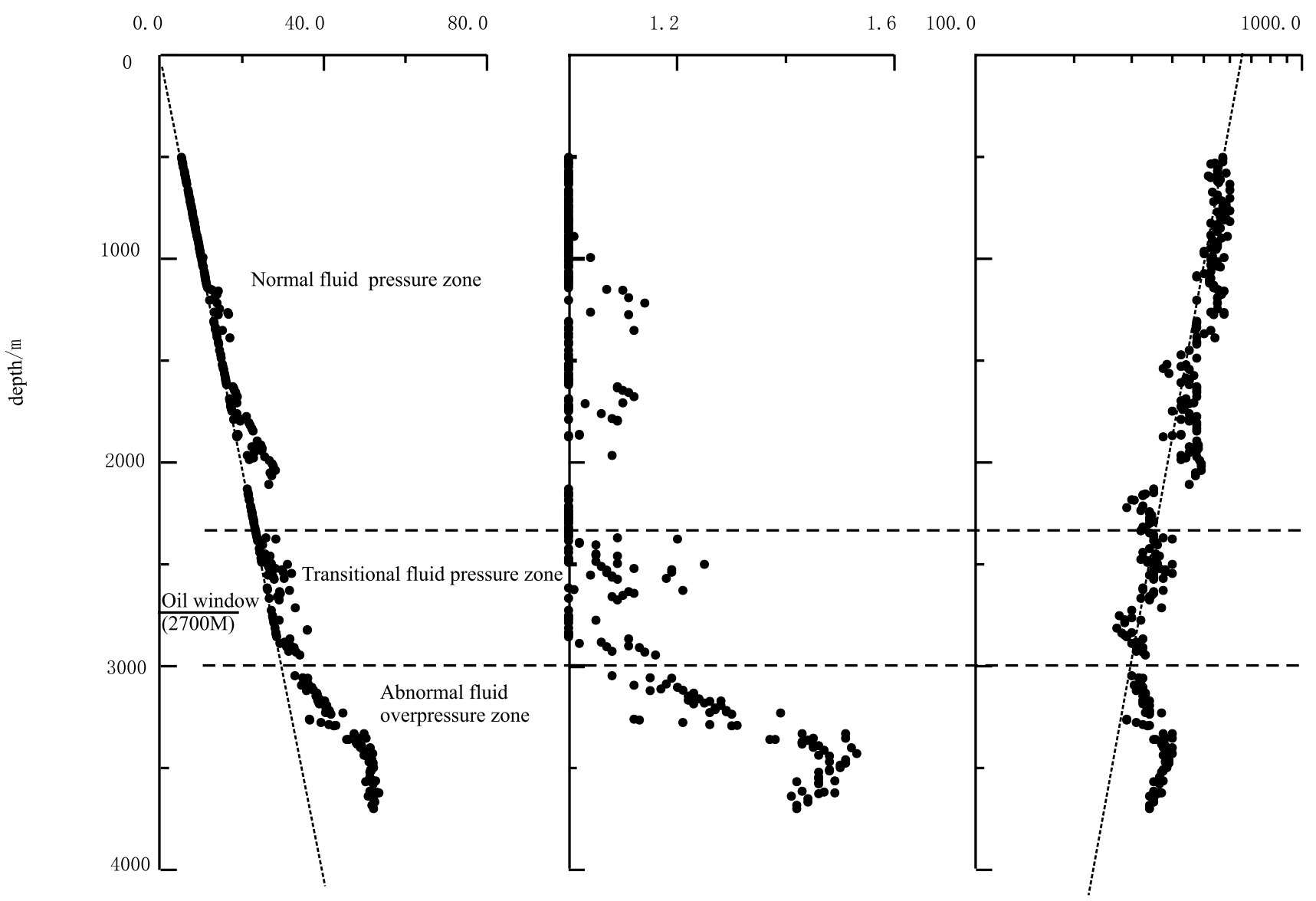

Fig. 11 Section of fluid pressure of well Li101 at Lijin sag

compaction disequilibrium is caused by quick deposition. For example, in well Niu38 the sedimentation rate of the upper part of Sq3-2 is approximately $800 \mathrm{~mm} / 1000$ years, and approximately $400-200 \mathrm{~mm} / 1000$ years for the lower part of Sq3-2 to Sq3-1 (Fig. 15). However, the higher overpressure in the Depression is present in the strata of the lower part of Sq3-2 to Sq3-1 and Sq2-2 (Figs. 13 and 14), which are deep lake deposits with slow sedimentation rate and are excellent source rocks for hydrocarbon (Fig. 15). Higher overpressure was not present in strata of the upper part of Sq3-2, which are prodeltaic deposits with higher sedimentation rates and are not a good source rock (Fig. 15). Based on the fluid pressure, PC, and EFP predicted using sonic logging, the top surface of the abnormal overpressure zone ( $\mathrm{PC}<1.2$ or EFP $>0$ ) was located at a depth of 2700-3000 m (Figs. 13 and 14). This is in agreement with the oil window $(2700 \mathrm{~m}$ ) of the $\mathrm{Sq} 3-2$ to Sq3-1 and Sq2-2 source rocks. This evidence shows that overpressure in the depression was likely caused by hydrocarbon generation, if the rate of volume increase resulted from the transformation of high-density organic matter to low-density fluids (oil or gas) exceeded the rate of volume loss caused by fluid migration and expulsion (Berg et al. 1999; Lee and Williams 2000; Fossen et al. 2010; Dasgupta et al. 2016; Hooker et al. 2017). This overpressure mechanism relies on the kerogen type, density of organic matter, rock permeability, and thermal history (Osborne and Swarbrick 1997; Tingay et al. 2009; Dixit et al. 2017). These excellent source rocks of the Depression, located in Sq3-1 and Sq2-2, have dominant kerogen types I to II, an oil window at 2700, and contain tight reservoirs ( $\mathrm{Li}$ and Pang 2004). These conditions favor overpressure caused by hydrocarbon generation.

The overpressure is a dynamic factor overcoming capillary resistance (Li and Pang 2004). The relationship between porosity and the pressure of sand bodies with oil-bearing saturation exceeding $80 \%$ in lithologic traps was studied by $\mathrm{Li}$ and Pang (2004). They found that porosity was the reverse ratio to fluid pressure in oil-bearing sandstone. Higher overpressure is favorable for hydrocarbon accumulation in the 


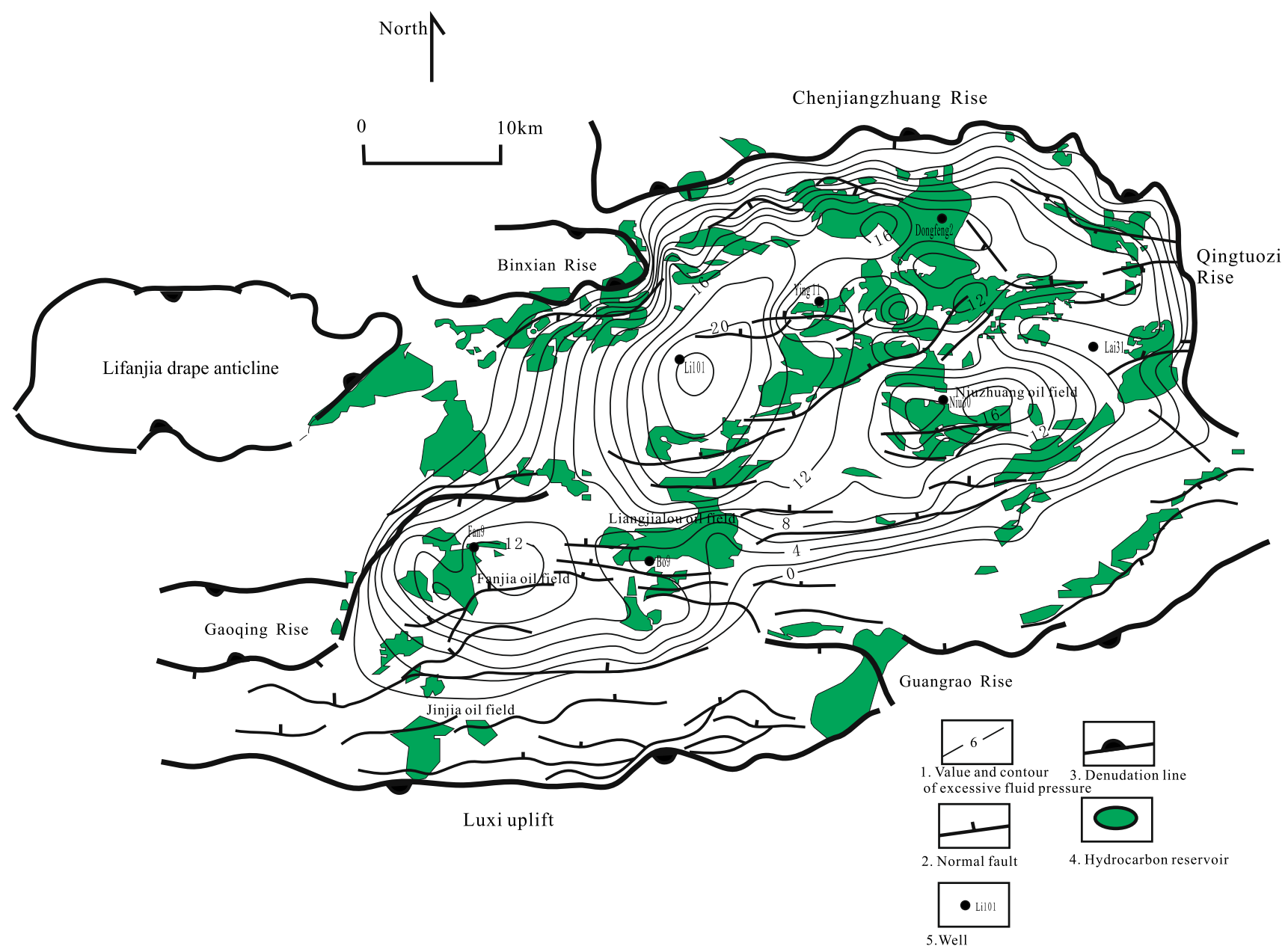

Fig. 12 Distribution of hydrocarbon reservoirs and EFP contours of mudstone on Sq3-2 top surface (middle part of third member of Shahejie Formation). EFP is excessive fluid pressure
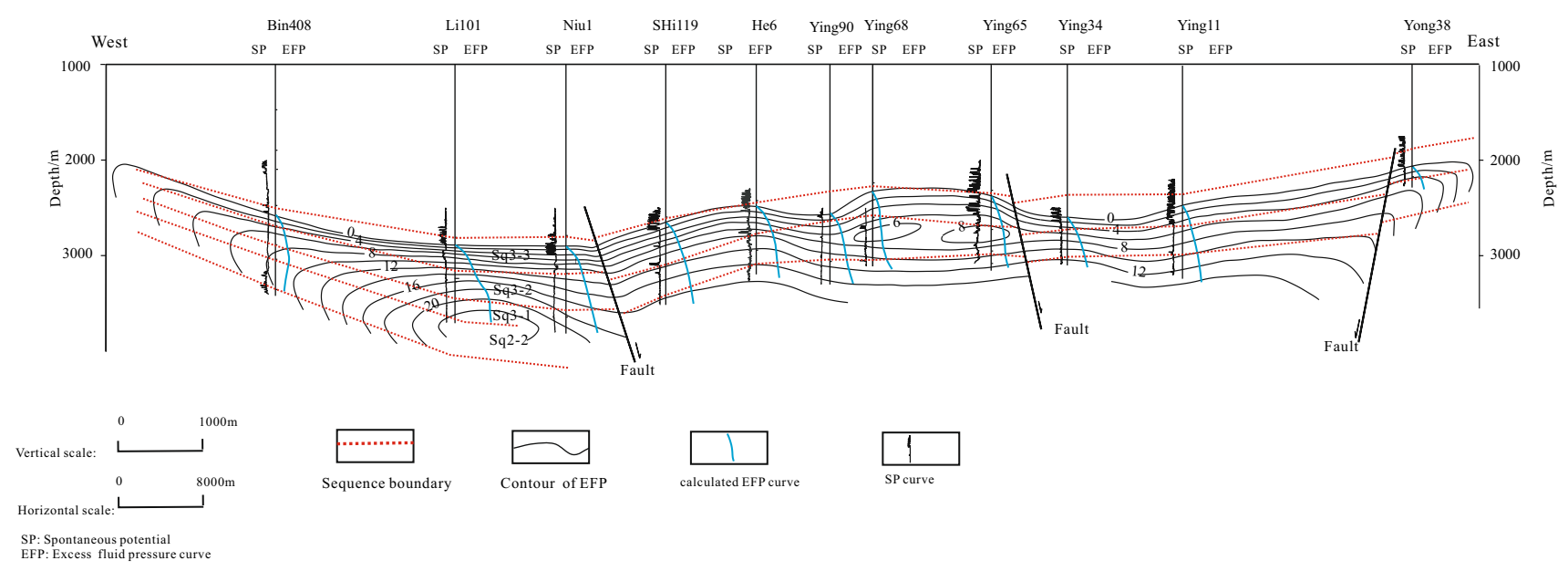

Fig. 13 Profile of well-tied EFP in the depression from East to West. The location of the profile (5) is indicated in Fig. 1b. EFP is excessive fluid pressure 


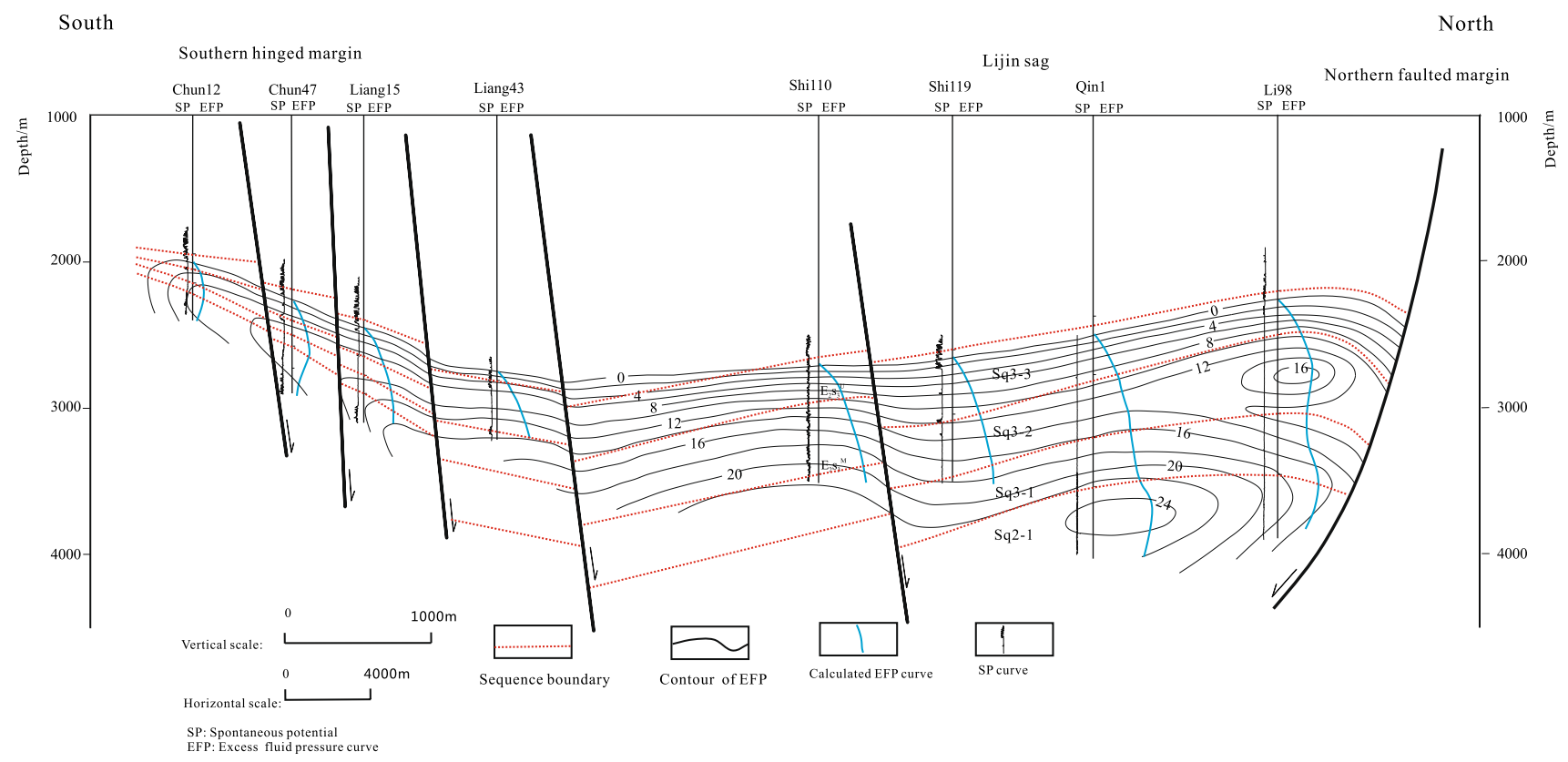

Fig. 14 Profile of well-tied EFP in the depression from north to south. The location of the profile (6) is indicated in Fig. 1b. EFP is excessive fluid pressure

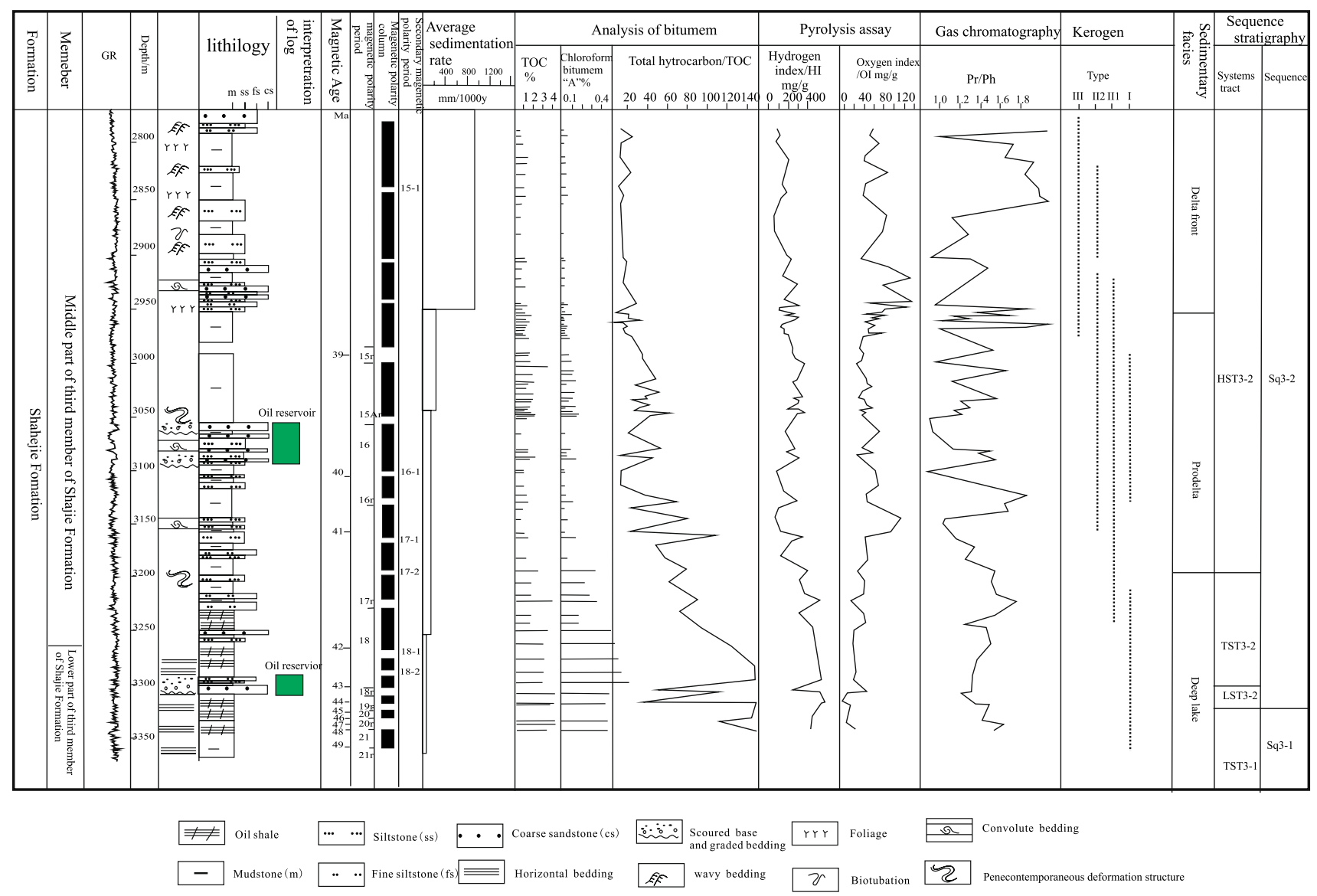

Fig. 15 Column of lithology, Paleomagnetic dating, sedimentary rate, and organic geochemistry in Well Niu 38 
tight sandstones of lenticular lithologic traps in particular (Li and Pang 2004). For example, in the Liangjialou and Niuzhuang oilfields, based on the DST data, lithologic reservoirs in Sq3-1 and Sq3-2 and Sq2-2 have overpressure and high oil-bearing saturation ( $\mathrm{Li}$ and Pang 2004; Guo et al. 2010; Hao 2013).

\section{Distribution of subtle reservoirs}

Subtle reservoirs are important exploration targets in the Depression (Li et al. 2004) and have special distribution characteristics.

\subsection{Distribution of lithologic reservoirs}

The lithologic reservoirs were distributed at overpressure zones of the depression, which are located at the centers and slopes of sags in Sq2-1, Sq3-1, and Sq3-2, e.g., Niuzhuang, Minfeng, Lijin, and Boxing sags (Figs. 7, 12, and 16). The lithologic traps are composed of lenticular turbidite fan and beach bar sand bodies or upward pitchout of sand bodies within source rocks of Sq2-2, Sq3-1, and Sq3-2, such as lithologic reservoirs in Nuizhang, Boxing, and Lijin sags (Figs. 7 and 8). They were distributed in Sq2-2, Sq3-1, and Sq3-2 source rocks at fluid overpressure zones of the center of sags; the overpressure is a dynamic factor overcoming capillary resistance of tight reservoirs to form lithologic reservoirs in source rocks ( $\mathrm{Li}$ and Pang 2004), for example, the Ying 11 hydrocarbon reservoir in the lithologic trap at fluid overpressure zone of the Lijin sag, and the Niuzhuang oilfield of the lithologic reservoir in the fluid overpressure zone of the Niuzhuang sag (Figs. 7, 12, and 16).

\subsection{Distribution of lithologic and structural combination reservoirs}

The hydrocarbon reservoirs in lithologic and structural combination traps were distributed in syndepositional faults or slope-break zones and near anticlines and fluid overpressure to transitional pressure zones of the slopes in the sags (Figs. 7, 9, 10, and 16). In the sequence stratigraphic framework, the hydrocarbon reservoirs in lithologic and structural combination traps were located in LSTs. For example, (1) the Liangjialou oilfield is a typical hydrocarbon reservoir in a structural and lithologic combination trap located in LST3-3 within Sq3-3 on

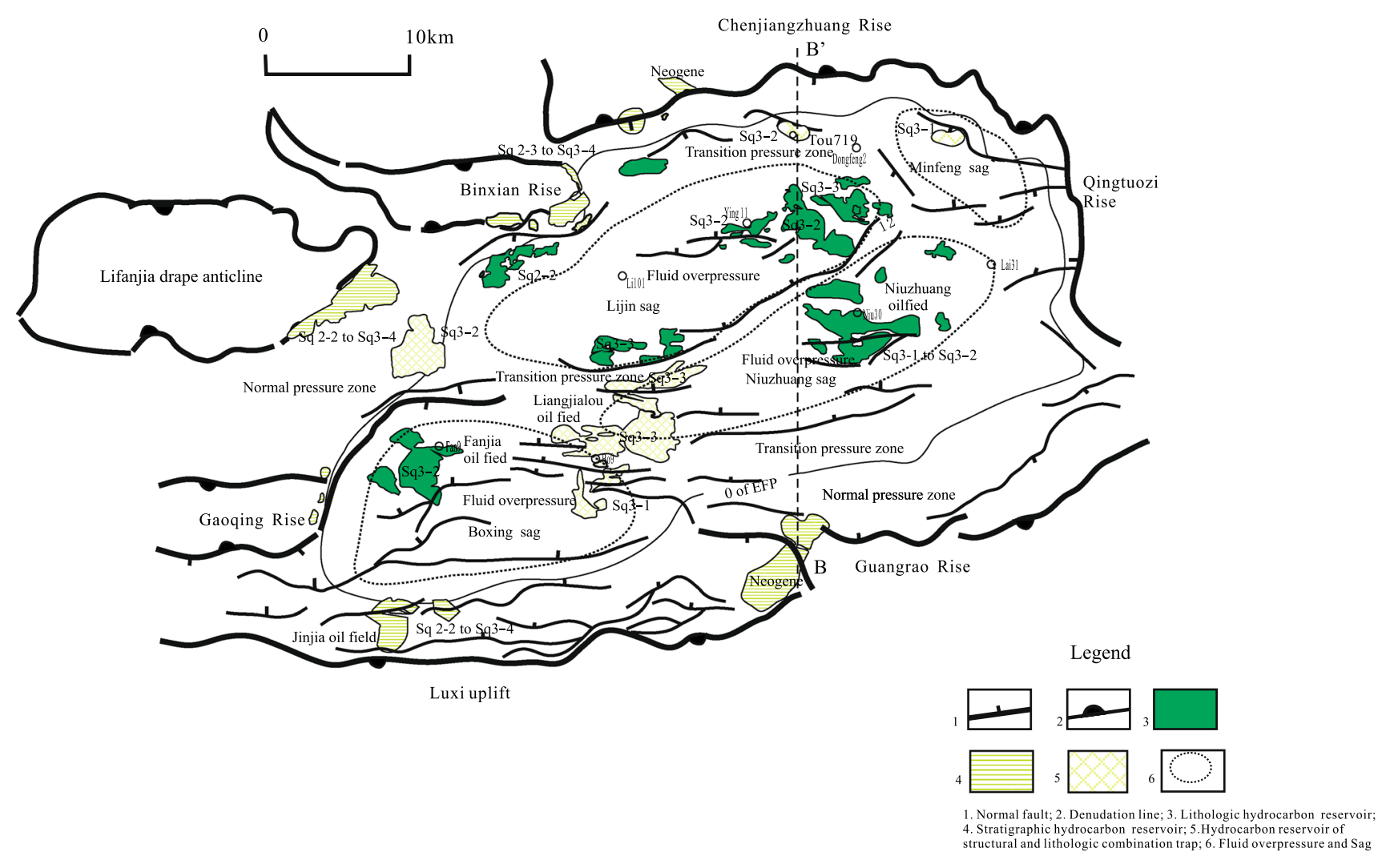

Fig. 16 Relationship between distribution of subtle reservoirs and fluid pressure field in Dongying Depression 
the southern hinged margin (Fig. 9). The sand bodies of sublacustrine fans and channels controlled by syndepositional faults or slope breaks developed in LST3-3 (Feng et al. 2013); they were capped by deep lake mudstone in TST3-3. Based on the correlation between source rocks and oil, the oil migrated from the Sq2-2 and Sq3-1 source rocks because of the higher gammacerane content and lower $\mathrm{Pr} / \mathrm{Ph}$ ratio (Li et al. 2010). In the Sq2-2 and Sq3-1 source rocks in the fluid overpressure zone (Figs. 11 and 12), the hydrocarbon, driven by overpressure, migrated up faults and accumulated in the structural and lithologic combination traps. The pressure coefficients of the hydrocarbon reservoirs obtained using DST ranged from 1.2 to 1.48 , showing that the hydrocarbon reservoirs had overpressure (Feng et al. 2006). (2) Another example is the Tou71 hydrocarbon reservoirs in LST3-2 of Sq3-2 at the faulted margin (Fig. 10). The structural and lithologic combination traps consisted of fan deltaic sand bodies and normal faults in LST3-2, which were sealed by oil shale and deep gray mudstone or source rock. Hydrocarbon from overlain TST3-2 source rock and the deep interval Sq3-1 and Sq2-2 source rocks in overpressure migrated directly or up faults into the structural and lithologic combination traps.

The Liangjialou oilfield and Tuo71 hydrocarbon reservoirs are distributed at overpressure to transitional pressure zone of the margins of the Lijin sag source rocks (Fig. 16). Because the Sq3-1, Sq3-2, and Sq2-2 source rocks are in the overpressure zone, the oil-bearing fluid should be discharging episodically up the faults or microfractures from the overpressure zone to form subtle reservoirs. Normal faults play important roles in the migration of the hydrocarbon from the source rocks of deep intervals to the traps of shallow intervals. They are conduit systems for hydrocarbon migration (Losh 1998; Losh et al. 1999).

\subsection{Distribution of stratigraphic hydrocarbon reservoirs}

The stratigraphic hydrocarbon reservoirs occur near unconformities or sequence boundaries, which are normal fluid pressure areas in the Depression. First- and second-order unconformities or sequence boundaries are favorable for stratigraphic hydrocarbon reservoirs (Figs. 7, 8, 16, and 17). There are three reasons: (1) the stratigraphic traps were predominantly controlled by unconformities, specially firstand second-order unconformities, and in the up-dip direction stratigraphic traps are sealed by the unconformities; (2) the slope areas of the Depression, where a lot of conformities were developed, were the normal fluid pressure areas and the main direction for the migration of hydrocarbon;

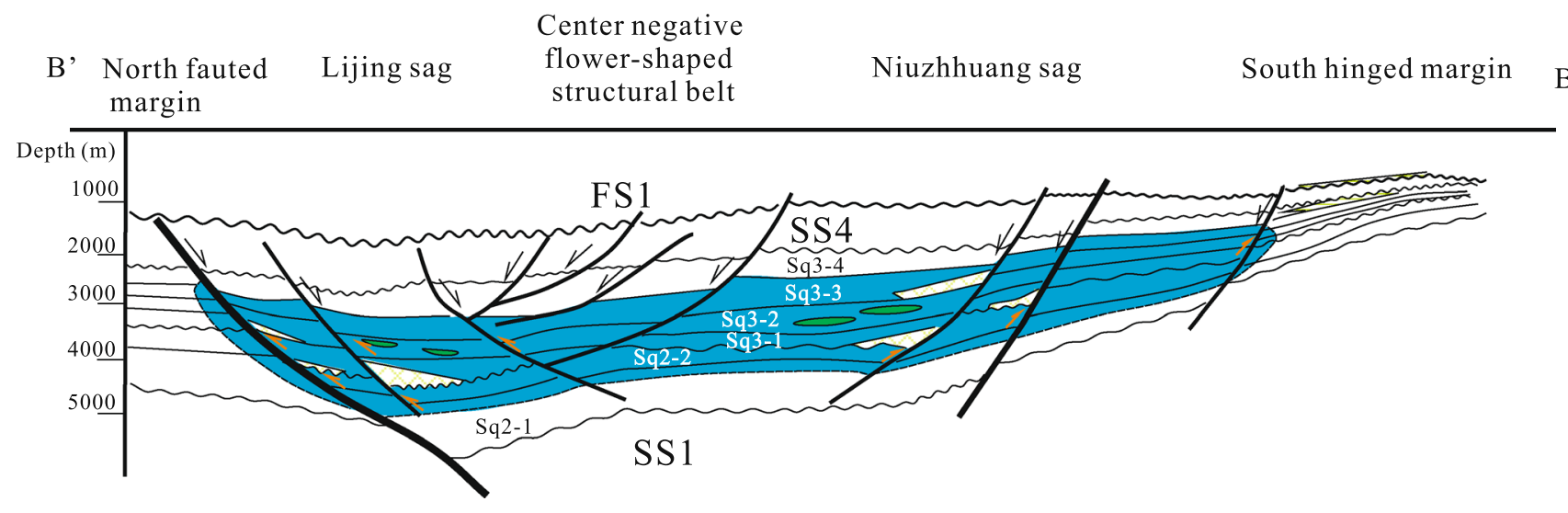

Legend

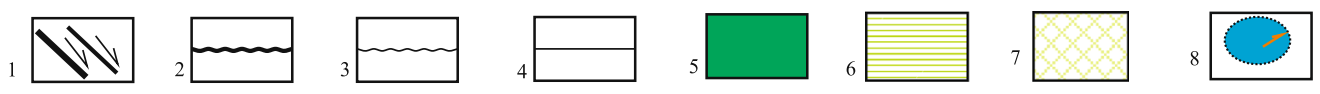

1. Second-and third- order normal faults; 2. First-order sequence surface; 3. Second-order sequence surface; 4. Third-order sequence surface; 5. Lithologic hydrocarbon reservoir; 6. Stratigraphic hydrocarbon reservoir; 7.Hydrocarbon reservoir of structural and lithologic combination trap; 8 . Overpressure and hydrocarbon migration direction

Fig. 17 Hydrocarbon reservoirs forming pattern of subtle traps within Shahejie Formation in Dongying Depression. The location BB' of the pattern is shown in Figs. $1 b$ and 16 
(3) the unconformities, normal faults, and sand bodies are conduits up and along which hydrocarbon can migrate from source rocks to the stratigraphic traps (Fig. 17).

Based on the described distribution features of subtle reservoirs above, the distribution of the subtle reservoirs shows cyclic features around the source rocks, such as the Lijin, Boxing, Niuzhuang, and Minfeng sags (Fig. 16). The lithologic reservoirs were distributed at fluid overpressure zones of the centers of sags, while structural and lithologic combination reservoirs were distributed on overpressure to transition pressure zones of the slope zones of sags. The hydrocarbon reservoirs in stratigraphic traps were distributed at the margins of source rock kitchens or sages in normal fluid pressure systems containing high-viscosity oil (Figs. 16 and 17). In addition, the hydrocarbon reservoirs in structural traps were distributed in normal fluid pressure systems too, for example, the hydrocarbon reservoirs in anticline and faulted-block traps in Sq3-4 and SS4.

\section{Controls of petroliferous plays of subtle traps in sequence stratigraphic framework}

Petroliferous plays of subtle traps are composed of subtle reservoirs. They are developed in special regions controlled by source rocks, sand bodies/reservoirs, unconformities/sequence boundaries, conduits, and fluid overpressure (Fig. 17).

Based on exploration data and the above analysis, the sand bodies within LSTs of sequences Sq2-2 to Sq3-3, controlled by syndepositional faults and incised channels, capped by mudstone and shale in TSTs of the sequences, constitute petroliferous plays of structural and lithologic combination traps in the fluid overpressure zone and transition pressure zone (Fig. 16). Syndepositional faults not only controlled the sand bodies in LSTs, but also were conduits up which the hydrocarbon in the deep intervals migrated to the subtle traps. Fluid-bearing oil forced by overpressure in Sq2-2 to Sq3-1, and Sq3-2 migrated up the faults and microfractures to the subtle traps. The relatively high paleogeothermal gradient anomalies in these areas, established by fluid inclusions, are strong evidence for the presence of overpressure hydrocarbon fluid migration (Feng et al. 2013).

Lenticular sand bodies (beach bars, small sublacustrine fans, gravity flow deposits of prodelta controlled by faults, slopes of prodelta, and slopes of paleorelief) developed in early HSTs to TSTs in sequences Sq2-2 to Sq3-2. There were also lithologic traps encased in mudstone and shale. Based on our research, hydrocarbon reservoirs in over $85 \%$ of the lenticular sand bodies have overpressure ( $\mathrm{Li}$ and Pang 2004). None of the oil-bearing lenticular sand bodies had near-normal fluid pressure (Zhang et al. 2004). The overpressure overcoming capillary resistance (Li and Pang 2004) favors hydrocarbon accumulation in the lithologic traps (Losh 1998; Losh et al. 1999; Li and Pang 2004). Correlation between the oil and source rocks shows that hydrocarbon in Sq3-1 and Sq3-2 lenticular sand bodies originated mainly from $\mathrm{Sq} 2-2$ and $\mathrm{Sq} 3-1$ source rocks. The faults and microfractures may act as conduit systems ( $\mathrm{Li}$ et al. 2010; Guo et al. 2014). The microfractures may be related by hydrofracturing associated with episodic hydrocarbon expulsion in the overpressure zone of the depression (Xie et al. 1998).

The hydrocarbon reservoirs associated with unconformities or sequence surfaces were petroliferous plays of stratigraphic traps. First- and second-order unconformities/sequence boundaries were laterally continuous throughout the whole depression and dominant stratigraphic traps were associated with them. The stratigraphic traps developed at the margins of the depression, which were the predominant destinations for hydrocarbon migration. The traps were charged by hydrocarbon migrating from the overpressure source rocks up faults, along sand bodies, and unconformities (Guo et al. 2014; Figs. 7 and $8)$. The first- and second-order unconformities controlled the distribution of the petroliferous plays of stratigraphic traps in particular (Fig. 17).

\section{Conclusion}

1. The sand bodies in the LSTs are controlled by syndepositional normal faults or slope breaks. The sand bodies within the TSTs to early HSTs are controlled by slopes of prodelta and paleorelief. These sand bodies are good reservoirs in lithologic and structural combination and lithologic traps.

2. Abnormal overpressure, developed mainly in Sq2-2 and Sq3-1 and Sq3-2, is a dynamic mechanism for hydrocarbon migration through conduit systems, such as faults, unconformities, and sand bodies.

3. Sand bodies within LSTs to early HSTs, covered by mudstone and shale in TSTs and early HSTs, are petroliferous plays in lithologic and structural combination traps and lithologic traps.

4. The petroliferous plays in stratigraphic traps are controlled by unconformities at margins of the depression.

Acknowledgements The authors thank Petroleum Geological Institute of Shengli Oil Field Corporation Ltd., Sinopec Corp., for their support and permission to use industry data for this research. The three reviewers are thanked for their constructive comments. 
Open Access This article is distributed under the terms of the Creative Commons Attribution 4.0 International License (http://creativeco mmons.org/licenses/by/4.0/), which permits unrestricted use, distribution, and reproduction in any medium, provided you give appropriate credit to the original author(s) and the source, provide a link to the Creative Commons license, and indicate if changes were made.

\section{References}

Allen MB, Macdonald DM, Zhao X, et al. Early Cenozoic two-phase extension and late Cenozoic thermal subsidence and inversion of the Bohai Basin, Northern China. Mar Pet Geol. 1997;14(78):951-72. https://doi.org/10.1016/S0264-8172(97)00027-5.

Berg RR, Gangi AF, et al. Primary migration by oil-generation microfracturing in low-permeability source rocks: application to the Austin Chalk, Texas. AAPG Bull. 1999;83(5):727-56.

Bredehoeft JD, Wesley JB, Fouch TD. Simulations of the origin of fluid-pressure, fracturegeneration, and movement of fluids in the Uinta Basin, Utah. AAPG. 1994;78:1729-47.

Brown LF, Benson JM, Brink GJ, et al. Sequence stratigraphy in offshore Southern African divergent basins-Front Matter. AAPG Stud Geol. 1995;41:1-184. https://doi.org/10.1002/9780470513 613.ch17.

Caillet G, Judge NC, Bramwell NP, et al. Overpressure and hydrocarbon trapping in the Chalk of the Norwegian Central Graben. Pet Geosci. 1997;3:33-42. https://doi.org/10.1144/petgeo.3.1.33.

Carroll AR, Bohacs KM. Stratigraphic classification of ancient lakes: balancing tectonic and climatic controls. Geology. 1999;27:99_ 102. https://doi.org/10.1130/0091-7613(1999)0272.3.

Chen DG, Peng ZC. K-Ar ages and Pb, Sr isotopic characteristic of Cenozoic volcanic rocks in Shandong, China. Geochimica. 1985;4:293-303 (in Chinese).

Chen Z, Huang W, Liu Q, et al. Geochemical characteristics of the Paleogene shales in the Dongying depression, eastern China. Mar Pet Geol. 2016;73:249-70. https://doi.org/10.1016/j.marpe tgeo.2016.02.022.

Dasgupta S, Chayyerjee R, Mohanty SP. Magnitude, mechanisms and prediction of abnormal pore pressure using well data in the Krishna Godavari Basin, East coast of India. AAPG Bull. 2016;100(12):1833-55. https://doi.org/10.1306/05131615170.

Dixit NC, Hanks CL, Wallace WK, et al. In situ stress variations associated with regional changes in tectonic setting, northeastern Brooks Range and eastern North Slope of Alaska. AAPG Bull. 2017;48(17):10107-15. https://doi.org/10.1021/es503013w.

Embry AF. Sequence boundaries and sequence hierarchies: problems and proposals. In: Steel RJ, Felt VL, Johannessen EP, Mathieu $\mathrm{C}$, editors. Sequence stratigraphy on the Northwest Margin. Norwegian Petroleum Society (NPS) Special Publication. 1995. pp. $1-11$.

Embry AF. Transgressive-regressive (T-R) sequence stratigraphy. In: Bob F, editors. 22nd Annual Gulf Coast Section SEPM Foundation. Perkings Research Conference. 2002. pp. 151-72.

Feng Y. Distribution of stratigraphic and lithologic reservoirs in sequence framework of rift-subsidence basin. Acta Pet Sin. 2005;26(4):17-22. https://doi.org/10.3321/j. issn:0253-2697.2005.04.004.

Feng Y, Jiang S, Hu S, et al. Sequence stratigraphy and importance of syndepositional structural slope-break for architecture of Paleogene syn-rift lacustrine strata, Bohai Bay Basin, E. China. Mar Pet Geol. 2016;69:183-204. https://doi.org/10.1016/j.marpe tgeo.2015.10.013.

Feng Y, Li S, Lu Y. Sequence stratigraphy and architectural variability in Late Eocene lacustrine strata of the Dongying depression,
Bohai Bay Basin, Eastern China. Sed Geol. 2013;295:1-26. https ://doi.org/10.1016/j.sedgeo.2013.07.004.

Feng Y, Li S, Zou C. Study on sequence stratigraphy in continental rift basin, a case study of Dongying depression Bohai Bay Basin. Beijing: Science Publishing House; 2006. p. 135-207 (in Chinese).

Feng YL. Tectono-magamatic evolution of Yangxing depression and its hydrocarbon accumulation. Oil Gas Geol. 1994;15(2):173-9. https://doi.org/10.11743/ogg19940210 (in Chinese).

Feng YL. Lower tertiary stratigraphic framework and basin filling model in Dongying depression (in Chinese with English summary). Earth Sci J China Univ Geosci. 1999;14(6):634-42 (in Chinese).

Feng YL, He LK, Zheng HR, et al. Gravity flow deposits of prodelta slope from $3^{\text {rd }}$ member of Shahejie Formation, Niuzhuang region, Shadong province. Oil Gas Geol. 1991;11(3):313-9 (in Chinese).

Feng YL, Li ST, Xie XL. Dynamics of sequence generation and sequence stratigraphic model in continental rift subsidence basin. Earth Sci Front. 2000;7(3):119-32. https://doi.org/10.3321/j. issn:1005-2321.2000.03.013 (in Chinese).

Feng YL, Zhou HM, Ren JY, et al. Paleogene sequence stratigraphy in the east of the Bohai Bay Basin and its response to structural movement. Sci China Earth Sci. 2010;40(10):1356-76. https://doi. org/10.3724/SP.J.1011.2010.01081 (in Chinese).

Fossen H, Schultz RA, Rundhovde E, et al. Fault linkage and graben step overs in the Canyon lands (Utah) and the North Sea Viking graben with the implications for hydrocarbon migration and accumulation. AAPG Bull. 2010;94(5):597-613. https://doi. org/10.1306/10130909088.

Godo TJ. Identification of stratigraphic traps with subtle seismic amplitude effects in Miocene channel/levee sand systems, NE Gulf of Mexico (in the deliberate search for the stratigraphic trap). Geol Soc Spec Publ. 2006;254:127-51. https://doi. org/10.1144/GSL.SP.2006.254.01.07.

Guo X, He S, Liu K, Song G, et al. Oil generation as the dominant overpressure mechanism in the Cenozoic Dongying depression, Bohai Bay Basin, China. AAPG Bull. 2010;94(12):1859-81. https://doi.org/10.1306/05191009179.

Guo X, Liu K, He S, et al. Petroleum generation and charge history of the northern Dongying Depression, Bohai Bay Basin, China: insight from integrated fluid inclusion analysis and basin modelling. Mar Pet Geol. 2012;32(1):21-35. https://doi.org/10.1016/j. marpetgeo.2011.12.007.

Guo S, Tan L, Lin C, et al. Hydrocarbon accumulation characteristics of beach-bar sandstones in the southern slope of the Dongying Sag, Jiyang Depression, Bohai Bay Basin, China. Pet Sci. 2014;11(2):220-33. https://doi.org/10.1007/s1218 2-014-0335-4.

Halbouty MT. Hidden trends and subtle traps in Gulf Coast. AAPG Bull. 1969;1969(53):3-29.

Han HX, Yin SD, Aadnoy BS. Impact of elliptical boreholes on in situ stress estimation from leak-off test data. Pet Sci. 2018;15:794800. https://doi.org/10.1007/s12182-018-0248-8.

Hao X. Overpressure genesis and evolution of sandstone reservoirs in the 3rd and 4th members of Shahejie Formation, the Dongying Depression. Oil Gas Geol. 2013;32(2):167-73. https://doi. org/10.11743/ogg20130204 (in Chinese).

Hao X, Chen H, Yang S, et al. Study on effective passage system in Liangjialou Oilfiel, Dongying Depression. Geol J China Univ. 2005;11(1):1-8. https://doi.org/10.1360/gs050303 (in Chinese).

Hooker JN, Cartwright J, Stepyenson B, et al. Fluid evolution in fracturing black shales, Appalachian Basin. AAPG Bull. 2017;101(8):1203-38. https://doi.org/10.1306/10031616030.

Hsiao LY, Graham SA, Tilander N. Seismic reflection imaging of a major strike-slip fault zone in a rift system: paleogene structure and evolution of the Tan-Lu fault system, Liaodong Bay, 
Bohai, offshore China. AAPG Bull. 2004;88:71-97. https://doi. org/10.1306/09090302019.

Hu CY. Source area controlling oil field distribution effective theory of regional exploration for continental basin in Eastern China (in Chinese with English abstract). Acta Pet Sin. 2010;3(2):9-13 (in Chinese).

Hubbard RJV. Depositional sequence boundaries on Jurassic and early Cretaceous rifted continental margins. AAPG Bull. 1988;1998(71):49-72.

Jiang S, Henriksen S, Wang H, Lu Y, et al. Sequence-stratigraphic architectures and sand-body distribution in Cenozoic rifted lacustrine basins, east China. AAPG Bull. 2013;97(9):1447-75. https ://doi.org/10.1306/03041312026.

Jiang ZX, Liang SY, Zhang YF, et al. Sedimentary hydrodynamic study of sand bodies in the upper subsection of the 4th Member of the Paleogene Shahejie Formation the eastern Dongying Depression, China. Pet Sci. 2014;11:189-99. https://doi.org/10.1007/s1218 2-014-0332-7.

Lahann RW. Gulf of Mexico overpressure and clay diagenesis without unloading: an anomaly. AAPG Bull. 2017;101(11):1859-77. https ://doi.org/10.1306/02071716191.

Lampe C, Song G, Cong L, et al. Fault control on hydrocarbon migration and accumulation in the Tertiary Dongying depression, Bohai Basin, China. AAPG Bull. 2012;96(6):983-1000. https://doi. org/10.1306/11031109023.

Lee M, Williams DD. Paleohydrology of the Delaware basin, western Texas. Overpressure development, hydrocarbon migration, and ore genesis. AAPG Bull. 2000;84(7):961-74. https://doi. org/10.1306/A9673B80-1738-11D7-8645000102C1865D.

Levorsen AI. The obscure and subtle trap. AAPG Bull. 1969;50:2058-67.

Li JR, Shan HG, Yao YM. A correlation of Tertiary Formations between the Jiyang-Changwei depressions and their adjacent area in Shandong province. Acta Pet Sin. 1992;13:33-5. https ://doi.org/10.7623/syxb199202005 (in Chinese).

Li S, Pang X, Jin Z, et al. Molecular and isotopic evidence for mixed source oils in subtle petroleum traps of the Dongying south slope, Bohai Bay Basin. Mar Pet Geol. 2010;27(7):1411-23. https://doi.org/10.1016/j.marpetgeo.2010.04.004.

Li S, Pang X, Li M, et al. Geochemistry of petroleum systems in the Niuzhuang South Slope of Bohai Bay Basin-Part 1: source rock characterization. Org Geochem. 2003;34:389-412. https://doi. org/10.1016/S0146-6380(02)00210-3.

Li P, Zhang S, Xiao H, et al. Exploration of subtle trap in Jiyang Depression. Pet Sci. 2004;1(2):13-21.

Li PL, Pang XQ. Hydrocarbon reservoir Formation of subtle traps in continental rift basin: a case study of Jiyang subbasin. Beijing: Petroleum Industrial Publishing House; 2004. p. 1-19 (in Chinese).

Lin C, Erisson K, Li S. Sequence architecture, depositional systems, and controls on development of lacustrine basin fills in part of the Erlian Basin, Northeast China. AAPG Bull. 2001;85:2017-43. https://doi.org/10.1306/8626D0DB-173B-11D7-8645000102 C1865D.

Lin CS, Ren JY, Zheng HR. The control of syn-depositional faulting on the Eogene sedimentary basin fills of the Dongying and Zhanhua sags, Bohai Bay Basin. Sci China Ser D. 2004;47:769-82. https ://doi.org/10.1360/03yd0203.

Liu J, Xia B, Wang J, et al. Sedimentary architecture of a sub-lacustrine debris fan: eocene Dongying Depression, Bohai Bay Basin, east China. Sed Geol. 2017;362:66-82. https://doi.org/10.1016/j.sedge o.2017.09.014.

Losh S. Oil migration in a major growth fault: structural analysis of the pathfinder core, south Eugene island, block330, offshore Louisiana. AAPG Bull. 1998;82(9):1694-710.
Losh SL, Eglinton LB, Schoell M, et al. Vertical and lateral fluid flow related to a large growth fault, South Eugene Island Block 330 Field, offshore Louisian. AAPG Bull. 1999;83(2):244-76.

Lu ZX, Zhang SL, Yin C, et al. Features and genesis of Paleogene high-quality reservoirs in lacustrine mixed siliciclastic-carbonate sediments, central Bohai Sea, China. Pet Sci. 2017;14:50-60. https://doi.org/10.1007/s12182-016-0147-9.

Luo X, Vasseur G. Contributions of compaction and aquathermal pressuring to geopressure and the influence of environmental conditions. AAPG Bull. 1992;76:1550-9.

Magara K. Reevaluation of montmorillonite dehydration as cause of abnormal pressure and hydrocarbon migration. AAPG Bull. 1975;59:292-302.

Mara RPT, Richard RH, Richar ES, et al. Origin of overpressure and porepressure prediction in the Baramprovince, Brunei. AAPG Bull. 2009;93(1):51-74. https://doi.org/10.1306/08080808016.

Martino R. Sequence stratigraphy of the Glenshaw Formation (middlelate Pennsylvanian) in the central Appalachina basin. In: Pashin JC, Gastaldo RA. editors. Sequence stratigraphy, paleoclimate, and tectonics of coal-bearing strata, vol. 51. AAPG Studies in Geology. 2004. pp. 1-2.

Maynard JR, Gibson GP. Potential for subtle traps in the Permian Rotliegend in UK southern North Sea. Pet Geosci. 2001;7:301-4. https ://doi.org/10.1144/petgeo.7.3.301.

Morley CK, Nelson RA, Patton TL, et al. Transfer zones in the East African rift system and their relevance to hydrocarbon exploration in rifts. AAPG Bull. 1990;74(8):1234-53.

$\mathrm{Mu} X$. Fault control on hydrocarbon migration and accumulation in the Tertiary Dongying depression, Bohai Basin, China. AAPG Bull. 2012;96(6):983-1000. https://doi.org/10.1306/11031109023.

Osborne MJ, Swarbrick RE. Mechanisms for generating overpressure in sedimentary basins: a reevaluation. AAPG Bull. 1997;81:102341. https://doi.org/10.1306/8626D379-173B-11D7-8645000102 C1865D.

Pang X, Chen D, Le M et al. Subtle traps in the Jiyang Superdepression of Bohai Bay basin: formation mechanisms and petroleum resource potential (in AAPG 2005 annual convention; abstracts volume), vol. 14. Abstracts: Annual Meeting - American Association of Petroleum Geologists. 2005. pp. A105.

Pang XQ, Jia CZ, Wang WY, et al. Petroleum geology features and research developments of hydrocarbon accumulation in deep petroliferous basins. Pet Sci. 2015;12:1-53. https://doi. org/10.1007/s12182-015-0014-0.

Paul D, Mitra S. Experimental models of transfer zones in rift systems. AAPG Bull. 2013;97(5):759-80. https://doi.org/10.1306/10161 212105.

Posamentier HW, Vail PR. Eustatic controls on clastic deposition, II: sequence and systems tract models. In: Wilgus CK, Hastings BS, Kendall CGSC, Posametier HW, Ross CA, Wagoner JC, editors. Seal-level changes: an integrated approach, vol. 42. SEPM, Special Publication. 1988. pp. 99-109.

Ramdhan AM, Goulty NR. Overpressure and mudrock compaction in the Lower Kutai Basin, Indonesia: a radical reappraisal. AAPG Bull. 2011;95(10):1725-44. https://doi.org/10.1306/0222111009 4.

Ren J, Tamaki K, Li S, et al. Late Mesozoicand Cenozoic rifting and its dynamic setting in eastern China and adjacent areas. Tectonophysics. 2002;344:175-205. https://doi.org/10.1016/S0040 -1951(01)00271-2.

Rosendahl BR. Architecture of continental rifts with special reference to East Africa. Annu Rev Earth Planet Sci. 1987;15:445-503. https://doi.org/10.1146/annurev.ea.15.050187.002305.

Rubey WW, Hubert MK. Role liquid pressure in mechanics of overthrust faulting. Geol Soc Am Bull. 1959;70:167-206. https://doi. org/10.1130/0016-7606(1959)70. 
Shanley KW, McCabe PJ. Perspective on the sequence stratigraphy of continental strata. AAPG Bull. 1994;78:544-68.

Song GQ, Wang YZ, Lu D, et al. Controlling factors of carbonate rock beach and bar development in lacustrine facies in the Chunxia submember of Member 4 of Shahejie Formation in south slope of Dongying Sag, Shandong Province. J Palaeogeogr. 2012;14:56570. https://doi.org/10.1007/s11783-011-0280-z (in Chinese).

Tingay MRP, Hillis RR, Swarbrick RE, et al. Origin of overpressure and porepressure prediction in the Baramprovince, Brunei. AAPG Bull. 2009;93(1):51-74. https://doi.org/10.1306/08080808016.

Van Wagoner JC, Mitchun RM, Campion KM, et al. Siliciclastic sequence stratigraphy in well, core and outcrops a concept for high resolution correlation of times and facies. AAPG Methods Explor Ser. 1990;7:1-55.

Wan TF. Tectonic outline in China. Beijing: Geological Publishing House; 2004. p. 176-9 (in Chinese).

Wang BH. Geological research and exploration in Shenli oil field. Dongying: Publishing House of Petroleum University; 1992. p. 1-350 (in Chinese).

Wang DD, Li ZX, Liu HL, et al. The genetic environmental transformation mechanism of coal and oil shale deposits in eastern China's continental fault basins and the developmental characteristics of the area's symbiotic assemblages-taking Huangxian Basin as an example. Pet Sci. 2019;16:469-91. https://doi.org/10.1007/s 1218 2-019-0308-8.

Wang YZ, Cao YC, Zhang SM, et al. Genetic mechanisms of secondary pore development zones of Es $4 \mathrm{x}$ in the north zone of the Minfeng Sag in the Dongying Depression, East China. Pet Sci. 2016;13:1-17. https://doi.org/10.1007/s12182-016-0076-7.

Wei PS, Su MJ. Methods for seismic sedimentology research on continental basins. Pet Sci. 2015;12:67-80. https://doi.org/10.1007/ s12182-014-0002-9.

Williams GD. Tectonics and Seismic sequence stratigraphy: an introduction. In: Williams GD, Dobb A, editors. Tectonics and Seismic sequence stratigraphy, vol. 71. Geological Society, Special Publication, London. 1993. pp. 1-13.

Xie X. Overpressure and petroleum generation and accumulation in the Dongying depression of the Bohaiwan Basin, China. Geofluids. 2001;1(4):257-71. https://doi.org/10.104 6/j.1468-8123.2001.00017.x.

Xie X, Liu X, Hu X, et al. Hydrofracturing and associated episodic hydrocarbon expulsion of mudstones in overpressure basin. Geol Sci Technol Inf. 1998;17(4):59-63 (in Chinese).

Yan G, Xu YH, Liu Y, et al. Evolution and organic geochemical significance of bicyclic sesquiterpanes in pyrolysis simulation experiments on immature organic-rich mudstone. Pet Sci. 2019;16:50212. https://doi.org/10.1007/s12182-019-0326-6.
Yang T, Cao YC, Wang YZ, et al. The coupling of dynamics and permeability in the hydrocarbon accumulation period controls the oil-bearing potential of low permeability reservoirs: a case study of the low permeability turbidite reservoirs in the middle part of the third member of Shahejie Formation in Dongying Sag. Pet Sci. 2016;13:204-24. https://doi.org/10.1007/s-12182-0099-0.

Yao YM, Liang HD, Cai ZG, et al. Paleogene of hydrocarbon-bearing districts in China (IV)-Volume of Bohai Bay Basin. Beijing: Publishing House of Petroleum Industry; 1994. p. 1-76 (in Chinese).

Yin BB, Li XF, Liu G. A mechanistic model of heat transfer for gasliquid flow in vertical wellbore annuli. Pet Sci. 2018;15:135-45. https://doi.org/10.1007/s12182-017-0193-y.

Zecchin M, Mellere D, Roda C. Sequence stratigraphy and architectural variability in growth fault-bounded basin fills: a review of PlioPleistocene stratal units of Croton basin, southern Italy. J Geol Soc. 2006;163:471-86. https://doi.org/10.1144/0016-764905-058.

Zeng H, Hentz TF. High-frequency sequence stratigraphy from seismic sedimentology: applied to Miocene, Vermilion Block 50, Tiger Shoal area, offshore Louisiana. AAPG Bull. 2004;88(2):153-74. https://doi.org/10.1306/C5676111-428C-405F-867706680D $1572 \mathrm{CC}$.

Zhang SW, Zhang LY, Zhang SC. Formation of abnormal high pressure and its application in the study of oil-bearing property of lithologic hydrocarbon reservoirs in the Dongying Sag. Chin Sci Bull. 2009a;54:4468-78. https://doi.org/10.1007/s11434-009-0200-9.

Zhang L, Liu Q, Zhu R, et al. Source rocks in Mesozoic-Cenozoic continental rift basins, east China: a case from Dongying Depression, Bohai Bay Basin. Org Geochem. 2009b;40(2):229-42. https://doi. org/10.1016/j.orggeochem.2008.10.013.

Zhang Q, Zhu XM, Ronald JS, et al. Variation and mechanisms of clastic reservoir quality in the Paleogene Shahejie Formation of the Dongying Sag, Bohai Bay Basin, China. Pet Sci. 2014;11:200-10. https://doi.org/10.1007/s12182-014-0333-6.

Zhang S, Wang Y, Shi D, et al. Fault-fracture mesh petroleum plays in the Jiyang Superdepression of the Bohai Bay Basin, eastern China. Mar Pet Geol. 2004;21:651-68. https://doi.org/10.1016/j. marpetgeo.2004.03.007.

Zong GH, Li CB, Xiao HQ. Evolution of Jiyang depression and its tectonic implications. Geol J China's Univ. 1999;5:275-82 (in Chinese).

Zou C, Wang L, Li Y, Tao S, et al. Deep-lacustrine transformation of sandy debrites into turbidites, Upper Triassic, Central China. Sed Geol. 2012;265-266:143-55. https://doi.org/10.1016/j.sedge o.2012.04.004.

Zou CN, Tao SZ, Hao XS. Connotation of "Facies Control Theory" and its significance for exploration. Pet Explor Dev. 2005;32(6):7-12. https://doi.org/10.1016/j.molcatb.2005.02.001. 